\title{
Natural Co-Occurrence of Mycotoxins in Foods and Feeds and Their in vitro Combined Toxicological Effects
}

\author{
Marie-Caroline Smith, Stéphanie Madec, Emmanuel Coton and Nolwenn Hymery * \\ Université de Brest, EA 3882 Laboratoire Universitaire de Biodiversité et d'Ecologie Microbienne, ESIAB, \\ Technopôle Brest-Iroise, 29280 Plouzané, France; marie-caroline.smith@univ-brest.fr (M.-C.S.); \\ stephanie.madec@univ-brest.fr (S.M.); emmanuel.coton@univ-brest.fr (E.C.) \\ * Correspondence: nolwenn.hymery@univ-brest.fr; Tel.: +33-2-9091-5100; Fax: +33-2-9091-5101
}

Academic Editor: Sven Dänicke

Received: 15 January 2016; Accepted: 21 March 2016; Published: 26 March 2016

\begin{abstract}
Some foods and feeds are often contaminated by numerous mycotoxins, but most studies have focused on the occurrence and toxicology of a single mycotoxin. Regulations throughout the world do not consider the combined effects of mycotoxins. However, several surveys have reported the natural co-occurrence of mycotoxins from all over the world. Most of the published data has concerned the major mycotoxins aflatoxins (AFs), ochratoxin A (OTA), zearalenone (ZEA), fumonisins (FUM) and trichothecenes (TCTs), especially deoxynivalenol (DON). Concerning cereals and derived cereal product samples, among the 127 mycotoxin combinations described in the literature, AFs+FUM, $\mathrm{DON}+\mathrm{ZEA}, \mathrm{AFs}+\mathrm{OTA}$, and FUM+ZEA are the most observed. However, only a few studies specified the number of co-occurring mycotoxins with the percentage of the co-contaminated samples, as well as the main combinations found. Studies of mycotoxin combination toxicity showed antagonist, additive or synergic effects depending on the tested species, cell model or mixture, and were not necessarily time- or dose-dependent. This review summarizes the findings on mycotoxins and their co-occurrence in various foods and feeds from all over the world as well as in vitro experimental data on their combined toxicity.
\end{abstract}

Keywords: mycotoxins; foodstuffs; regulations; co-occurrence; combined toxicological effects

\section{Introduction}

Mycotoxins are secondary fungal metabolites mainly produced by species from the Aspergillus, Penicillium, and Fusarium genera. These toxins are found all around the world as natural contaminants in numerous commodities of plant origin, especially in cereals grains, but also in nuts, oilseeds, fruits, dried fruits, vegetables, cocoa and coffee beans, wine, beer, as well as herbs and spices. Mycotoxins can also be found in animal-derived food if animals eat contaminated feed, namely meat, eggs, milk, and milk derivatives [1,2].

Mycotoxin production, especially on grains, is highly dependent on pre and/or postharvest environmental factors (e.g., temperature and moisture content). Climate represents the key factor in mycotoxin and fungal occurrence. Mycotoxins are climate-dependent compounds but several factors can affect their presence, such as bioavailability of micronutrients, insect damage making it a complex and multifactor phenomenon [3]. These metabolites are usually subdivided into field mycotoxins, produced on cereal crops before or immediately after harvest mainly by Fusarium spp., and storage mycotoxins, primarily secreted by Aspergillus and Penicillium spp. during commodity drying and storage [1].

Mycotoxin ingestion may induce various chronic and acute effects on humans and animals, such as hepatotoxic, genotoxic, immunosuppressive, estrogenic, nephrotoxic, teratogenic, and/or 
carcinogenic effects [1,4]. Moreover, mycotoxins are not completely eliminated during food processing operations and can contaminate finished processed food products $[5,6]$.

Their worldwide occurrence in various food and feeds poses a major risk for human and animal health and, as a consequence, causes economic losses [1]. Although these economic costs are impossible to estimate accurately, the United States Food and Drug Administration (FDA) evaluated, based on computer modeling, that in the USA the potential economic costs of crop losses due to mycotoxin contaminations average $\$ 932$ million per year [7]. The FAO (Food and Agriculture Organization of the United Nations) estimated that $25 \%$ of the world's crops are affected by mycotoxins each year, with annual losses of around 1 billion metric tons of food and food products (2007).

Among the thousands of fungal secondary metabolites currently known, only a few groups of mycotoxins are important from the safety and economic points of view; namely aflatoxins (AFs), mainly produced by Aspergillus species; ochratoxin A (OTA), produced by Aspergillus and Penicillium species, and zearalenone (ZEA), fumonisins (FUM) and trichothecenes (TCTs) (especially deoxynivalenol $(\mathrm{DON}))$, primarily produced by many Fusarium species [8-10]. Moreover, several species from the Fusarium genus can produce other mycotoxins with toxicological properties such as beauvericin (BEA), enniatins (ENNs), and moniliformin (MON), a group of lesser-studied toxins called emerging mycotoxins [11] (a non-exhaustive list of mycotoxin producing Aspergillus, Penicillium and Fusarium species, split into eight groups, is provided in Table 1). Even if these mycotoxin-producing fungi differ according to ecological conditions, it is important to emphasize that mycotoxins are found all over the world in foodstuffs and feedstuffs due to trade in these commodities that contributes to their worldwide dispersal. Moreover, Table 1 shows that one mycotoxin can be produced by several fungi, and that a fungus can produce several mycotoxins.

Several authors have shown an interest in cellular mechanisms and cellular toxicity in response to mycotoxin exposure. After ingestion by the consumer, the intestinal epithelium is the first host defense barrier against mycotoxins. However, although these cells are the first to be exposed to mycotoxins and at higher doses than other tissue cells, studies on the effect of mycotoxin mixtures on the gastrointestinal tract are scarce. Grenier and Appelgate [12] summarized in a recent review findings following major mycotoxin exposure (AFs, OTA, DON, T2, ZEA, and FUM) on digestive and absorptive functions, intestinal defense and microbiome composition. Briefly, they highlighted the large variability of mycotoxin bioavailability according to the considered mycotoxins and animal species. For example, the authors reported that more than $80 \%$ of AFs are absorbed within the gastrointestinal tract regardless of the non-ruminant species (via passive transport), whereas absorption of other major mycotoxins (TCT, OTA, or FUM) may vary from $1 \%$ to $60 \%$ (via passive transport by simple diffusion for OTA or via the paracellular route for DON). Moreover, several mycotoxins have been shown to undergo entero-hepatic circulation. This makes the mycotoxins available again via the bile in the entero-hepatic cycle, resulting in reabsorption and a prolonged retention time in the gastrointestinal tract. Intestinal metabolism in the gut epithelium and by the gut microbial population, limits the toxic effects of mycotoxins within the gastrointestinal tract. In particular, due to rumen microorganisms, ruminants are able to convert many mycotoxins into non-toxic metabolites before absorption, whereas for monogastrics, mycotoxin intestinal biotransformation takes place predominantly in the large intestine and thus provides little detoxification prior to absorption. However, little is known about the intestinal absorption and bacterial metabolism of the metabolites. Nevertheless, a recent in vitro study showed that the derivative 15-ADON caused the highest paracellular permeability and chemokine secretion compared to DON and 3-ADON in human intestinal cells Caco-2 [13]. Even if commensal microbiota is a key player in the detoxification against mycotoxins and their derivatives, it is important to note the potential of mycotoxins to enhance the toxic effects of intestinal pathogens and to change the intestinal microbiota balance by increasing the number of aerobic bacteria and thereby acting as a potential risk factor for chronic inflammatory diseases [12].

Because of their occurrence and toxicity, major mycotoxins (i.e., AFs, OTA, ZEA, FUM, and DON) are the focus of legal regulations or guidance in many countries. The Joint Expert Committee on 
Food Additives (JECFA), a scientific advisory body of the World Health Organization (WHO) and the FAO, evaluates mycotoxin risks. In the United States and the European Union, regulatory and recommended guidance for mycotoxins are issued by the FDA and the European Commission (EC) advised by the European Food Safety Authority (EFSA), respectively. To protect animal and human consumers, these regulations fixed regulatory threshold values in food and feed to ensure they are not harmful and recommended good agricultural practice. For example, the maximum levels (MLs) of EU regulatory limits range from $0.1 \mu \mathrm{g} / \mathrm{kg}$ for aflatoxin B1 (AFB1) in processed cereal-based foods for human infants and young children, to $4000 \mu \mathrm{g} / \mathrm{kg}$ for fumonisins B1 and B2 in unprocessed maize for human consumption. Concerning milk and milk-based products, MLs are $0.05 \mu \mathrm{g} / \mathrm{kg}$ for aflatoxin M1 (European Commission (EC) 2006 and subsequent amendments) [14]. Mycotoxin regulations differ across states, even if harmonization efforts are being undertaken in some trade zones. However, this harmonization would not necessarily be beneficial from a human health protection point of view because of the differences in contamination levels and dietary habits in various parts of the world [15]. In the developed world, the dietary exposure is below the mycotoxin tolerance limits and tolerable daily intakes established by the JECFA, but it is not always the case for developing countries, as reported by Shepard [16], with the example of maize-based diet. Moreover, with the intensive farming due to an increasing world population, and particularly in developing countries, the number of world inhabitants over-exposed to mycotoxins could be enhanced over the next few years.

Noteworthy, mycotoxins may occur in modified forms from their parent compounds, due mainly to plant detoxification systems. Indeed, as part of their defense against xenobiotics, plants can alter the chemical structure of mycotoxins by modifications generated by enzymes involved in detoxification processes. Because these modifications lead to modified chromatographic profiles, epitope conformation or polarity, these mycotoxin derivatives usually escape conventional analytical methods and are not regulated by legislation and thus are called "masked" mycotoxins. Even if in the case of several studied conjugated mycotoxins, a lower toxicity was observed compared to the parent compounds, a potential increased bioavailability during digestion of masked mycotoxins still represent a health threat $[17,18]$. As masked mycotoxins are an emerging issue and insufficient toxicological and quantification data are available, these metabolites will not be considered in this review.

Concerning the routinely screened mycotoxins, the current regulations were established on toxicological data from studies taking into account only one mycotoxin exposure at a time, and do not consider the combined effects of mycotoxins. However, the natural co-occurrence of mycotoxins in cereals grains is well-known, and can be explained by at least three reasons: (i) most fungi are able to produce several mycotoxins concurrently (Table 1); (ii) food commodities can be contaminated by several fungi simultaneously or in quick succession and (iii) animal diets are usually made up of multiple grain sources. This is supported by a three-year worldwide survey that indicates that $48 \%$ of 7049 analyzed feedstuffs samples were contaminated by two or more mycotoxins [19]. This multi-contamination risk exposure is particularly true for ruminants, which have varied diets compared to other farm animals. In particular, ruminants are fed with forages, which are commonly contaminated with several mycotoxins, as reported in the recent review from Gallo et al. [20]. These authors highlighted the lack of data concerning mycotoxin occurrence in silages and other forage crops, and recommended to analyze forages for nutritive and fermentative characteristics, but also mainly for mycotoxin contaminations.

The toxicity of mycotoxins combinations cannot always be predicted based upon their individual toxicities. Multi-exposure may lead to additive, synergistic or antagonistic toxic effects $[6,21]$. The data on combined toxic effects of mycotoxins are limited, thus the health risk from this multi-exposure is not well-known.

The aims of this present review are to display the main natural mycotoxin mixtures found in common foods, such as cereals, nuts, fruits, milk and processed products thereof, and feedstuffs, to summarize current regulations as well as the published experiments on these mycotoxin mixtures, and 
to describe their known toxicological effects. This work may potentially underline areas lacking data for better taking into consideration this problem.

\section{Mycotoxin Regulations}

The last survey of the FAO in 2003 reported that, on a worldwide basis, around 100 countries, representing approximatively $87 \%$ of the world population, had regulations or detailed guidelines for mycotoxins or groups of mycotoxins in food and/or feed. Because of the various factors playing a role in the decision-making process to establish mycotoxin limits, including scientific, economic and political factors, the permitted limits and the mycotoxins targeted by legislation vary from country to country [15]. For example, the European Commission (EC) has issued maximum permitted levels for six groups of mycotoxins for animal feed: AFs, OTA, ZEA, FUM, DON, and rye ergot, and seven groups for human food: AFs, OTA, ZEA, FUM, DON, patulin (PAT) and citrinin (CIT); whereas only three groups are regulated by the FDA for animal feed (AFs, FUM, and DON) and one more for human food (PAT).

\subsection{Aflatoxins}

Regarding total aflatoxins (i.e., sum of AFB1, AFB2, AFG1, and AFG2) in human food, EU MLs are $4 \mu \mathrm{g} / \mathrm{kg}$ for peanuts and other oilseeds, tree nuts, dried fruits, cereals, and processed products thereof, intended for direct human consumption or use as ingredient in foodstuffs; $10 \mu \mathrm{g} / \mathrm{kg}$ for tree nuts, dried fruits, maize and rice subjected to sorting, or other physical treatment, before human consumption as well as spices, dried figs, almonds, pistachios, apricot kernels, hazelnuts, and Brazil nuts intended for direct human consumption; and $15 \mu \mathrm{g} / \mathrm{kg}$ for peanuts and other oilseeds, almonds, pistachios, apricot kernels, hazelnuts, and Brazil nuts subjected to sorting, or other physical treatment, before human consumption [14]. The FDA action level is $20 \mu \mathrm{g} / \mathrm{kg}$ for total AFs in peanuts, Brazil nuts, pistachios, and other foods for direct human consumption [22].

Regarding animal feed, EU MLs have been issued for aflatoxin B1 only and range from $20 \mu \mathrm{g} / \mathrm{kg}$ for feed materials to $10 \mu \mathrm{g} / \mathrm{kg}$ for complementary and complete feed, with the exception of compound feed for young animals (MLs are $5 \mu \mathrm{g} / \mathrm{kg}$ ) [23]. In comparison, the action levels established by the FDA for AFs range from $20 \mu \mathrm{g} / \mathrm{kg}$ for corn, peanut products, and other animal feeds and ingredients for immature and dairy animals, to $100 \mu \mathrm{g} / \mathrm{kg}$ for corn and peanut products for breeding cattle, breeding swine and immature poultry, $200 \mu \mathrm{g} / \mathrm{kg}$ for finishing swine and $300 \mu \mathrm{g} / \mathrm{kg}$ for finishing beef cattle as well as cottonseed meal for beef, cattle, swine or poultry, regardless of age or breeding status [22].

For milk and milk-based products, only aflatoxin M1 is considered, and EU MLs are $0.05 \mu \mathrm{g} / \mathrm{kg}$ [14]. Indeed, AFM1 is metabolized and excreted in the milk after the ingestion of its parent molecule, AFB1, by dairy cattle. The action levels established by the FDA are 10 times higher than the EU MLs for AFM1 in milk (namely $0.5 \mu \mathrm{g} / \mathrm{kg}$ ) [22].

\subsection{Ochratoxin $A$}

OTA MLs in the EU are $0.5 \mu \mathrm{g} / \mathrm{kg}$ for processed cereal-based foods and baby foods; $2 \mu \mathrm{g} / \mathrm{kg}$ for wine, grape juice, grape nectar and grape must intended for direct human consumption; $3 \mu \mathrm{g} / \mathrm{kg}$ for products derived from unprocessed cereals; $5 \mu \mathrm{g} / \mathrm{kg}$ for unprocessed cereal, roasted coffee beans and ground roasted coffee; $10 \mu \mathrm{g} / \mathrm{kg}$ for dried vine fruit and soluble coffee; $15 \mu \mathrm{g} / \mathrm{kg}$ for certain spices; $20 \mu \mathrm{g} / \mathrm{kg}$ for liquorice root for herbal infusion and $80 \mu \mathrm{g} / \mathrm{kg}$ for liquorice extract for use in food in particular beverages and confectionery [14]. 
Table 1. Some mycotoxins of interest and their fungal source, with primary food and feed hosts and endemic regions. References: [1,2,4,24-32].

\begin{tabular}{|c|c|c|c|}
\hline Mycotoxin & Fungi Source & Product of Primary Concern & Geographical Occurrence \\
\hline $\mathrm{AFs} *(\mathrm{~B} 1, \mathrm{~B} 2, \mathrm{G} 1, \mathrm{G} 2)$ & $\begin{array}{l}\text { Aspergillus (bombycis, flavus, nomius, ochraceoroseus, } \\
\text { parasiticus, parvisclerotigenus, pseudotamarii, rambellii, } \\
\text { toxicarius) }\end{array}$ & $\begin{array}{l}\text { Cereals and cereal-based products (mainly corn), } \\
\text { nuts, nut products and seeds, dried fruits, spices, } \\
\text { milk and dairy products, meat, eggs }\end{array}$ & $\begin{array}{l}\text { Temperate, tropical and subtropical } \\
\text { regions (Southern Asia and Africa) }\end{array}$ \\
\hline OTA * & $\begin{array}{l}\text { Aspergillus (alliaceus, auricomus, carbonarius, cretensis, } \\
\text { flocculosus, glaucus, lacticoffeatus, meleus, niger, } \\
\text { ochraceus, pseudoelegans, roseoglobulosum, } \\
\text { sclerotioniger, sclerotiorum, steynii, sulphureus, } \\
\text { westerdijkiae); Penicillium (nordicum, verrucosum) }\end{array}$ & $\begin{array}{l}\text { Cereals and cereal-based products (mainly rice and } \\
\text { wheat), coffee and cocoa beans; wine, beer, dried } \\
\text { fruits, spices, meat }\end{array}$ & $\begin{array}{l}\text { From cool-temperate to tropical regions } \\
\text { (Northern and Southern America, } \\
\text { Northern and Western Europe, } \\
\text { Africa and South Asia) }\end{array}$ \\
\hline TCTs * (DON, NIV, T-2, HT-2, DAS) & $\begin{array}{l}\text { Fusarium (acuminatum, armeniacum, culmorum, } \\
\text { crookwellense, equisetii, graminearum, kyushuense, } \\
\text { langsethiae, poae, pseudograminearum, sambucinum, } \\
\text { scirpi, sporotrichioides, venamtum) }\end{array}$ & All cereals and cereal-based products & $\begin{array}{l}\text { Northern temperate regions } \\
\text { (Europe, America and Asia) }\end{array}$ \\
\hline ZEA* & $\begin{array}{l}\text { Fusarium (crookwellense, culmorum, equiseti, } \\
\text { graminearum, incarnatum, pseudograminearum, } \\
\text { semitectum, sporotrichioides, verticillioides) }\end{array}$ & All cereals and cereal-based products, and banana & $\begin{array}{l}\text { Northern temperate regions } \\
\text { (Europe, America and Asia) }\end{array}$ \\
\hline FUM * (B1, B2, B3) & $\begin{array}{l}\text { Fusarium (anthophilum, dlamini, fujikuroi, globosum, } \\
\text { napiforme, nygamai, oxysporum, polyphialidicum, } \\
\text { proliferatum, pseudonygamai, thapsinum, verticillioides) }\end{array}$ & Corn, millet, sorghum, rice and their derivatives & Hot-temperate regions (Europe, Africa) \\
\hline BEA * & $\begin{array}{l}\text { Fusarium (acuminatum, armeniacum, anthophilum, } \\
\text { avenaceum, beomiforme, dlamini, equiseti, fujikuroi, } \\
\text { globosum, langsethiae, longipes, nygamai, oxysporum, } \\
\text { poae, proliferatum, pseudoanthophilum, sambucinum, } \\
\text { semitectum, sporotrichioides, subglutinans) }\end{array}$ & All cereals and cereal-based products & Temperate regions (Europe) \\
\hline ENs * (A, A1, B, B1) & $\begin{array}{l}\text { Fusarium.(acuminatum, avenaceum, langsethiae, } \\
\text { lateritium, poae, proliferatum, sambucinum, } \\
\text { sporotrichioides, tricinctum) }\end{array}$ & All cereals and cereal-based products & Temperate regions (Europe) \\
\hline MON * & $\begin{array}{l}\text { Fusarium (acuminatum, avenaceum, culmorum, equiseti, } \\
\text { fujikuroi, napiforme, nygamai, oxysporum, proliferatum, } \\
\text { pseudonygamai, sporotrichioides, subglutinans, } \\
\text { thapsinum, tricinctum, verticillioides) }\end{array}$ & All cereals and cereal-based products & Temperate regions (Europe) \\
\hline
\end{tabular}

zearalenone (ZEA); fumonisins (FUM); beauvericin (BEA); enniatins (ENs); moniliformin (MON). 
For animal consumption, MLs are $250 \mu \mathrm{g} / \mathrm{kg}$ for feed materials, $50 \mu \mathrm{g} / \mathrm{kg}$ for complementary and complete feeding stuffs for pigs, and $100 \mu \mathrm{g} / \mathrm{kg}$ for poultry [33].

The FDA does not establish regulatory guidance for this toxin.

\subsection{Fumonisins}

Concerning FUM, the EC has set MLs for the sum of fumonisins B1 and B2, ranging from $200 \mu \mathrm{g} / \mathrm{kg}$ for processed cereal-based and baby foods for infants and young children, to $4000 \mu \mathrm{g} / \mathrm{kg}$ for unprocessed maize. FUM may also be found in other common foods such as maize and maize-based foods intended for direct human consumption (MLs are $1000 \mu \mathrm{g} / \mathrm{kg}$ ), or maize-based breakfast cereals and snacks (MLs are $800 \mu \mathrm{g} / \mathrm{kg}$ ) [14]. The FDA guidance levels for the sum of fumonisins B1, B2, and B3 are between $2000 \mu \mathrm{g} / \mathrm{kg}$ and $4000 \mu \mathrm{g} / \mathrm{kg}$ for maize and maize-based products intended for human food [34].

Moreover, MLs for the sum of FB1 and FB2 are $60,000 \mu \mathrm{g} / \mathrm{kg}$ for maize and maize products in feed materials and range from $5000 \mu \mathrm{g} / \mathrm{kg}$ to $50,000 \mu \mathrm{g} / \mathrm{kg}$ for complementary and complete feeding stuffs, depending on the species and the age of the animal (MLs are $5000 \mu \mathrm{g} / \mathrm{kg}$ for pigs, equids, rabbits and pet animals, $10,000 \mu \mathrm{g} / \mathrm{kg}$ for poultry, calves, lambs and kids, and 50,000 $\mu \mathrm{g} / \mathrm{kg}$ for adult ruminants and mink) [33]. The FDA guidance levels for the sum of FB1, FB2, and FB3 range from $5000 \mu \mathrm{g} / \mathrm{kg}$ to $100,000 \mu \mathrm{g} / \mathrm{kg}$ for corn and corn by-products in animal feed according to species and age (FDA guidance levels are $5000 \mu \mathrm{g} / \mathrm{kg}$ for equids and rabbits, $20,000 \mu \mathrm{g} / \mathrm{kg}$ for swine and catfish, $30,000 \mu \mathrm{g} / \mathrm{kg}$ for breeding ruminants, poultry and mink, $60,000 \mu \mathrm{g} / \mathrm{kg}$ for ruminants being raised for slaughter and mink being raised for pelt production, $100,000 \mu \mathrm{g} / \mathrm{kg}$ for poultry being raised for slaughter, and 10,000 $\mu \mathrm{g} / \mathrm{kg}$ for all other species and classes of livestock) [34].

\subsection{Zearalenone}

EU MLs for ZEA in human food are $20 \mu \mathrm{g} / \mathrm{kg}$ for processed maize-based foods for infants and young children, and processed cereal-based foods; $50 \mu \mathrm{g} / \mathrm{kg}$ for bread, pastries, biscuits, cereal snacks and breakfast cereals; $75 \mu \mathrm{g} / \mathrm{kg}$ for cereals intended for direct human consumption; $100 \mu \mathrm{g} / \mathrm{kg}$ for maize, maize-based snacks, maize-based breakfast cereals and unprocessed cereals; $350 \mu \mathrm{g} / \mathrm{kg}$ unprocessed maize and $400 \mu \mathrm{g} / \mathrm{kg}$ for refined maize oil [14]. The FDA does not establish regulatory guidance for this toxin.

For feed materials, MLs range from $2000 \mu \mathrm{g} / \mathrm{kg}$ for cereals and cereal products, to $3000 \mu \mathrm{g} / \mathrm{kg}$ for maize products. Concerning complementary and complete feeding stuffs, MLs range from $100 \mu \mathrm{g} / \mathrm{kg}$ for piglets and young sows, to $250 \mu \mathrm{g} / \mathrm{kg}$ for sows and fattening pigs and $500 \mu \mathrm{g} / \mathrm{kg}$ for calves, dairy cattle, sheep, and goats [33].

\subsection{Trichothecenes}

Regarding DON in human food, MLs range from $200 \mu \mathrm{g} / \mathrm{kg}$ for processed cereal-based and baby foods to 1750 and $1250 \mu \mathrm{g} / \mathrm{kg}$ for unprocessed durum wheat, oats, and maize as well as other unprocessed cereals, respectively. DON may also be found in other common foods such as cereals intended for direct human consumption and pasta (in this case MLs are $750 \mu \mathrm{g} / \mathrm{kg}$ ), as well as bread, pastries, biscuits, cereal snacks, and breakfast cereals (MLs are $500 \mu \mathrm{g} / \mathrm{kg}$ ) [14]. The FDA advisory level for DON is $1000 \mu \mathrm{g} / \mathrm{kg}$ for finished wheat products intended for direct human consumption [35], and thus is close to the EU MLs. Currently, levels are under discussion for the sum of T-2 and HT-2 toxins in unprocessed cereals and cereals products for human consumption in the EU [14].

For feed materials, the EU MLs range from $8000 \mu \mathrm{g} / \mathrm{kg}$ for cereals and cereal products, to $12,000 \mu \mathrm{g} / \mathrm{kg}$ for maize by-products. EU MLs for complementary and complete feeding stuffs are $5000 \mu \mathrm{g} / \mathrm{kg}$ expect for pigs (MLs are $900 \mu \mathrm{g} / \mathrm{kg}$ ) and calves, lambs and kids (MLs are $2000 \mu \mathrm{g} / \mathrm{kg}$ ) [33]. For grain and grain by-products in animal feed, the FDA advisory levels range from $5000 \mu \mathrm{g} / \mathrm{kg}$ to $10,000 \mu \mathrm{g} / \mathrm{kg}$ (according to the considered species and the age of the animal) [35], whereas due to the relatively low human exposure to the other TCTs, such as nivalenol (NIV) and diacetoxyscirpenol 
(DAS), and their co-occurrence with typically more abundant DON, establishing maximum permitted levels for these toxins is currently not considered [14]. However, due to their possible additive or synergistic toxic effects, it would be interesting to establish regulations for total TCTs, as it is already the case with AFs and FUM.

\subsection{Other Regulated Mycotoxins}

Regarding patulin (PAT), the EU MLs are $10 \mu \mathrm{g} / \mathrm{kg}$ for apple juice and solid apple products, including apple compote and apple purée, for infants and young children. Moreover, MLs are $25 \mu \mathrm{g} / \mathrm{kg}$ for solid apple products for direct human consumption and $50 \mu \mathrm{g} / \mathrm{kg}$ for fruit juices, spirit drinks, cider and other fermented drinks derived from apples or containing apple juice [14]. FDA regulatory limits are $50 \mu \mathrm{g} / \mathrm{kg}$ for apple juice and apple juice component of a food that contains apple juice as an ingredient [36].

EU MLs for citrinin (CIT) are $2000 \mu \mathrm{g} / \mathrm{kg}$ for food supplements based on rice fermented by the "red yeast" Monascus purpureus [14].

MLs for rye ergot in the EU are $1000 \mathrm{mg} / \mathrm{kg}$ for feed materials and compound feed containing ungrounded cereals [33].

Thus, the European Community has one of the most stringent regulations in the world, with numerous mycotoxins and commodities concerned, and more restrictive levels. However, like the other regulations in the world, the EC does not consider the combined toxicological effects of mycotoxins.

\section{Natural Co-Occurrence of Mycotoxins in Foods and Feeds}

Several surveys reported the natural co-occurrence of mycotoxins from all over the world, and most of them concerned the major mycotoxins AFs, OTA, ZEA, FUM, and TCTs-especially DON. However, only a few studies specified the number of co-occurring mycotoxins with the percentage of the co-contaminated samples, as well as the main combinations found. We selected the relevant data and papers (from 1987 to present) from over a hundred papers dealing with mycotoxin co-occurrence in different foods and feeds. Only studies with at least 10 samples were considered.

As presented in Figure 1a, more than $60 \%$ of the information comes from Europe, whereas merely $7 \%$ is obtained from North America, and only one paper studied samples from Oceania. Concerning the commodity types, raw and processed cereals are the most frequently studied, representing $80 \%$ of the overall data. The rest of the data mainly concerns plant products, especially fruits, spices, and nuts, and only a few studies were focused on milk and its derivatives (Figure 1b). Overall, about $50 \%$ of the data concerning cereals and cereal based-products comes from Europe (data not shown). Additionally, amongst the 107 included studies [37-143], about 35\% was published between 2011 and 2015, highlighting the increasing interest for worldwide mycotoxin co-occurrence.

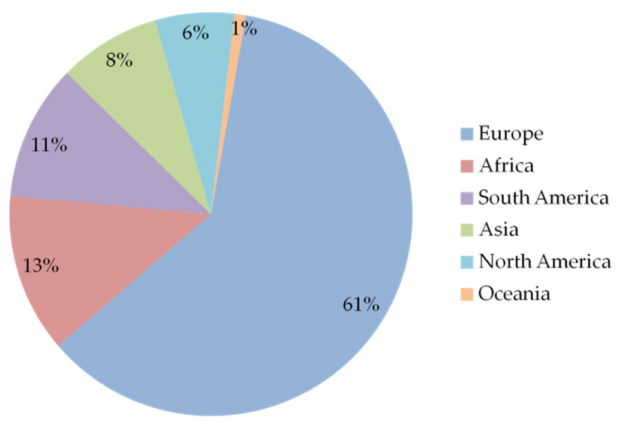

(a)

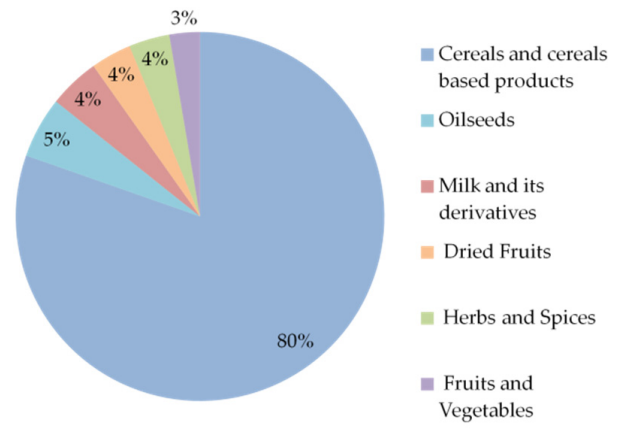

(b)

Figure 1. Data distribution depending on (a) geographic regions and (b) commodities. Data compiled from 107 articles. References: [37-143]. 
The difficulty of comparing studies using different methodologies of mycotoxin detection and quantification should be emphasized, considering their associated sensitivity and accuracy variations. Indeed, since 1972, we have witnessed a tremendous evolution of chromatographic and immuno-techniques. Especially since 2011 with the development of LC or GC-MS/MS that can detect ever more co-occurring mycotoxins. Moreover, some authors focused on only certain mycotoxins while others developed non-targeted approaches, which also complicates qualitative and quantitative comparisons. For example, the last worldwide mycotoxin survey [144] found up to 75 co-occurring mycotoxins in a same sample from a LC-MS/MS analysis targeting more than 380 mycotoxins simultaneously, whereas up to seven co-occurring mycotoxins were found in a same sample among the 107 papers analyzed, with a more "classic" approach targeting less than 15 major mycotoxins [123].

The main mixtures reported in these articles were analyzed by commodity type (cereals and cereals based-products, herbs and spices, dried fruits, fruits and vegetables, oilseeds, and milk and its derivatives) and by region (Europe, Africa, Asia, South America, and North America). Because only one study cites a sample coming from New Zealand, Oceania was not included.

\subsection{Results by Commodity Type}

Among the 116 mycotoxin combinations found by the authors in cereal and derived cereal product samples, AFs+FUM, DON+ZEA, AFs+OTA, and FUM+ZEA were the most present. These mixtures are quoted $21,14,12$, and 11 times out of the 91 papers analyzing cereal products, respectively, representing $23 \%, 15 \%, 13 \%$, and $12 \%$ of these articles respectively. Furthermore, the last survey by the BIOMIN Company showed that DON, FUM, and ZEA are the most prevalent mycotoxins in the world, with a prevalence of $66 \%, 56 \%$, and $53 \%$, respectively, among the 6844 analyzed agricultural commodity samples [144]. Because of their common co-occurrence, also potentially associated with AFs (with a worldwide prevalence of 22\%) [144], these mycotoxin toxicological interactions must not be disregarded.

Only four papers focused on herbs and spices $[68,75,110,122]$. In all of them, AFs+OTA mixtures were listed. The other combinations found corresponded to OTA+ZEA, AFs+ZEA, and AFs+OTA+ZEA, quoted twice for OTA+ZEA and AFs+OTA+ZEA, and once for AFs+ZEA.

Dried fruits were also studied in four papers $[45,68,74,127]$. In this context, the AFs+OTA mixture was cited three times and AFs + cyclopiazonic acid (CPA) only once.

Among the three articles concerning fruits and vegetables, apples have been extensively studied [73,101,124]. Five mycotoxin mixtures were reported in these articles and none of the authors found the same mixtures. It should be noted that PAT was quoted twice in combination with either AFs or CIT.

The same observation was made for oilseeds (nuts, tree nuts, soy, olives): among the 11 mixtures quoted in six papers, all are cited only once $[59,60,63,120,122,123]$. The combinations listed were mainly formed with TCTs.

Concerning milk and its derivatives, mainly cheeses, only three mixtures have been reported: Roquefortine-C (ROQ-C) + mycophenolic acid (MYC-A), AFs+OTA, and AFs+CPA. These combinations were quoted 2-, 2- and 1-times out of five articles, respectively $[42,66,86,91,108]$. Other animal products, like meat or eggs, have not been studied in a co-occurrence context.

Using this literature set, it can be summarized that AFs are found in various food and feed products, often in combination with OTA or fusariotoxins (mainly FUM and ZEA). Generally, binary mixtures are the most common among about 25 mycotoxins studied in the 107 papers, even if the last BIOMIN survey showed, that among the worldwide samples tested on average 30 different metabolites were detected per sample using a multi-mycotoxin technique (LC-MS-MS) [144]. 


\subsection{Results by Region}

The relation between geographical origin and reported mycotoxin combinations is presented in Figure 2. For European samples, among the 105 mycotoxin mixtures found, the most reported one (16 out of 67 publications, or $24 \%$ ) was AFs+OTA. While, DON+ZEA, DON+NIV, and DON+T2 combinations were quoted in $15 \%, 13 \%$, and $12 \%$ of these articles, respectively. The other combinations were listed in less than $10 \%$ of the articles.

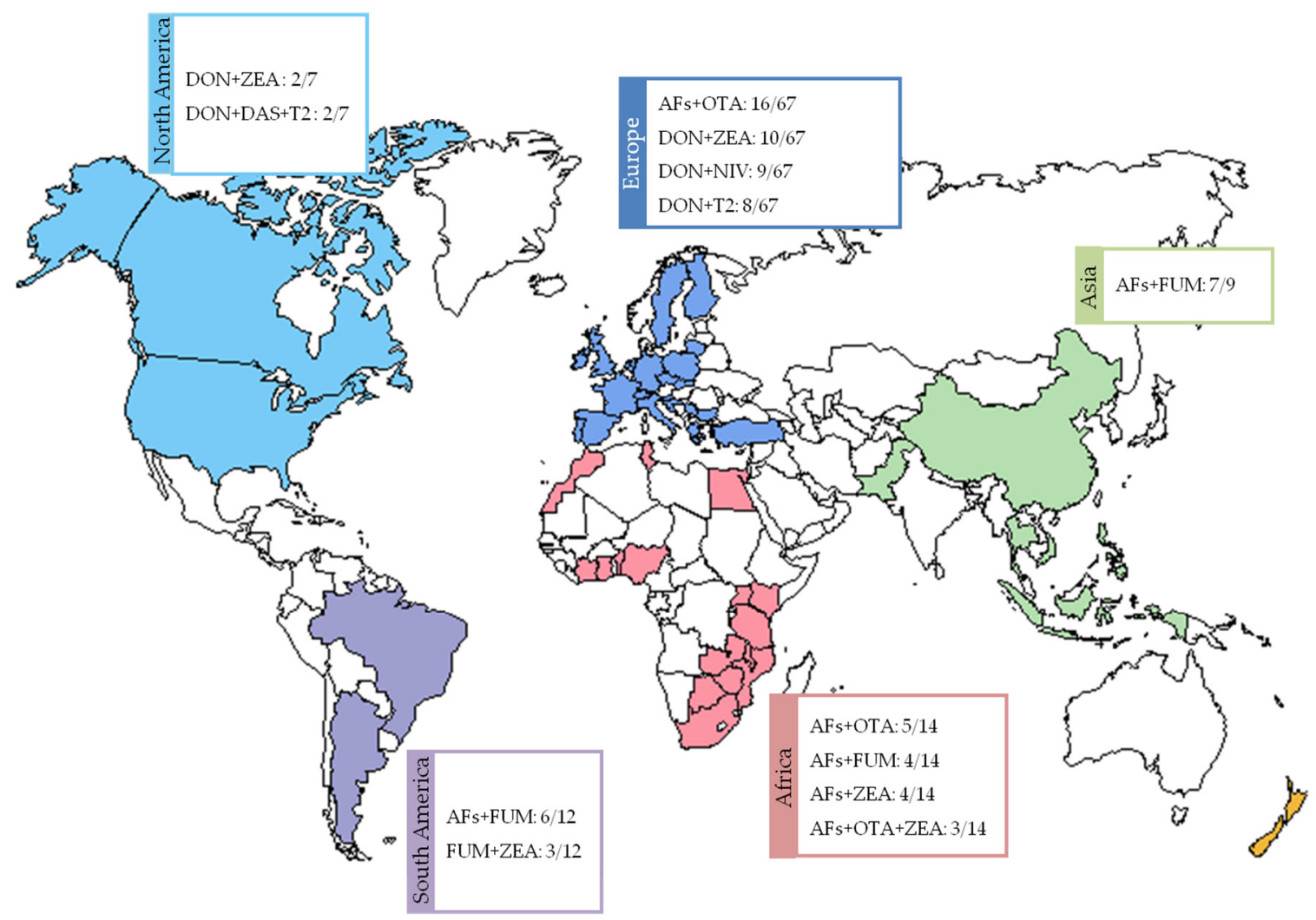

Figure 2. Main mycotoxin mixtures quoted in the papers depending on their geographic origin. Data compiled from 107 articles. References: [37-143].

Concerning African samples, over the 26 observed mycotoxins combinations, AFs+OTA was once again, the main mixture, representing $35 \%$ of the 14 publications related to African samples. The $\mathrm{AFs}+\mathrm{FUM}$ and AFs+ZEA binary combinations as well as the AFs+OTA+ZEA ternary combination were cited in $29 \%, 21 \%$, and $29 \%$ of these articles, respectively. The other mixtures were observed in only two or less articles.

In Asia, AFs+FUM was the most observed mixture (seven out of nine articles, or $78 \%$ ) among the 18 listed combinations. The other combinations were reported in only one or two articles. It can be highlighted that AFs or FUM were present in almost all the other mixtures.

In South America, more particularly in Brazil and Argentina, AFs+FUM was also the most observed mixture, as it was reported in $50 \%$ (six out of 12 articles). While FUM+ZEA was the second most observed combination (25\%) among the 12 listed mycotoxins mixtures. 
Concerning the seven publications from North America, 21 mycotoxin combinations were reported, the main ones being DON+ZEA and DON+DAS+T2, quoted in two papers $(29 \%)$, respectively.

In conclusion regarding the occurrence and prevalence aspect, the AFs+FUM mixture is the most prevalent in Africa, Asia, and South America (Figure 2). Maize harvested in the tropical and subtropical areas of the world with hot and humid climates is the major commodity contaminated with the two toxins. Aflatoxins are a far greater problem in the tropics than in temperate zones of the world. However, because of the movement of agricultural commodities around the globe, no region of the world is aflatoxin-free. In more temperate and cold regions (Europe and North America), mixture of TCTs or TCTs with ZEA are the most common, highlighting the importance of the climate conditions on fungal contamination, growth, metabolism and thus mycotoxin mixtures. Fusarium is the main genus implicated in TCTs production and many toxigenic Fusarium species have been associated with infected grain. The geographical distribution of the Fusarium species is probably related to environmental temperature requirements and/or different agricultural practices [145].

Overall, among the 127 mycotoxin mixtures described by the authors from all combined countries and commodities, the main mycotoxin mixtures cited were AFs+OTA, AFs+FUM, and DON+ZEA, found in $21 \%, 20 \%$, and $13 \%$ of the studies. Cereals represent the main OTA and ZEA sources of human intake $[146,147]$. Among cereal grains, AFs and ZEA mainly appear in corn (EFSA, 2004; EFSA 2007), whereas barley has a particularly high likelihood of OTA contamination [148]. Over the past few years, there has been emerging evidence of potential aflatoxin contamination of feed materials grown in areas of southern Europe, where a subtropical climate and extensive agricultural practice favor fungal growth and the subsequent formation of aflatoxins (EFSA, 2007). However, it is important to note that our analysis did not consider the "year" parameter, and it is well known today that prevalence and contamination levels of mycotoxins vary greatly according to harvest year of the cereals [149]. Moreover, climatic and agricultural practice changes observed over the last years, including the reduction of fungicide use, could lead to mycotoxin contamination in food [150,151].

Based on the data organized by region, a dendogram was created using the "HeatMap" function of the "R Project for Statistical Computing" software and a hierarchical ascendant classification analysis using the "hclust" function and with the default parameter "ward's method". This graphic representation, corresponding to a qualitative approach, is a heat-grey plot matrix illustration, in which the grey color intensity depends on the number of times that a mycotoxin combination mixture is cited (Figure 3). Asia and South America exhibit similar profiles; they are as close to Africa's profile as the same mixtures, with a similar number of reports, have been observed. Despite the fact that EU regulations are one of the most stringent in the world, Europe exhibits a large range of mixtures cited compared to the other regions but it is worth nothing that European studies were more extensive as they represent $61 \%$ of the 106 studied articles. Thus, the significant difference in the number of publications by region could also impact on the results. Nevertheless, North America has the closest profile to Europe. This analysis was supported by the above comments which highlighted the role of climate in mixture occurrence and potentially by similar agricultural methods. 


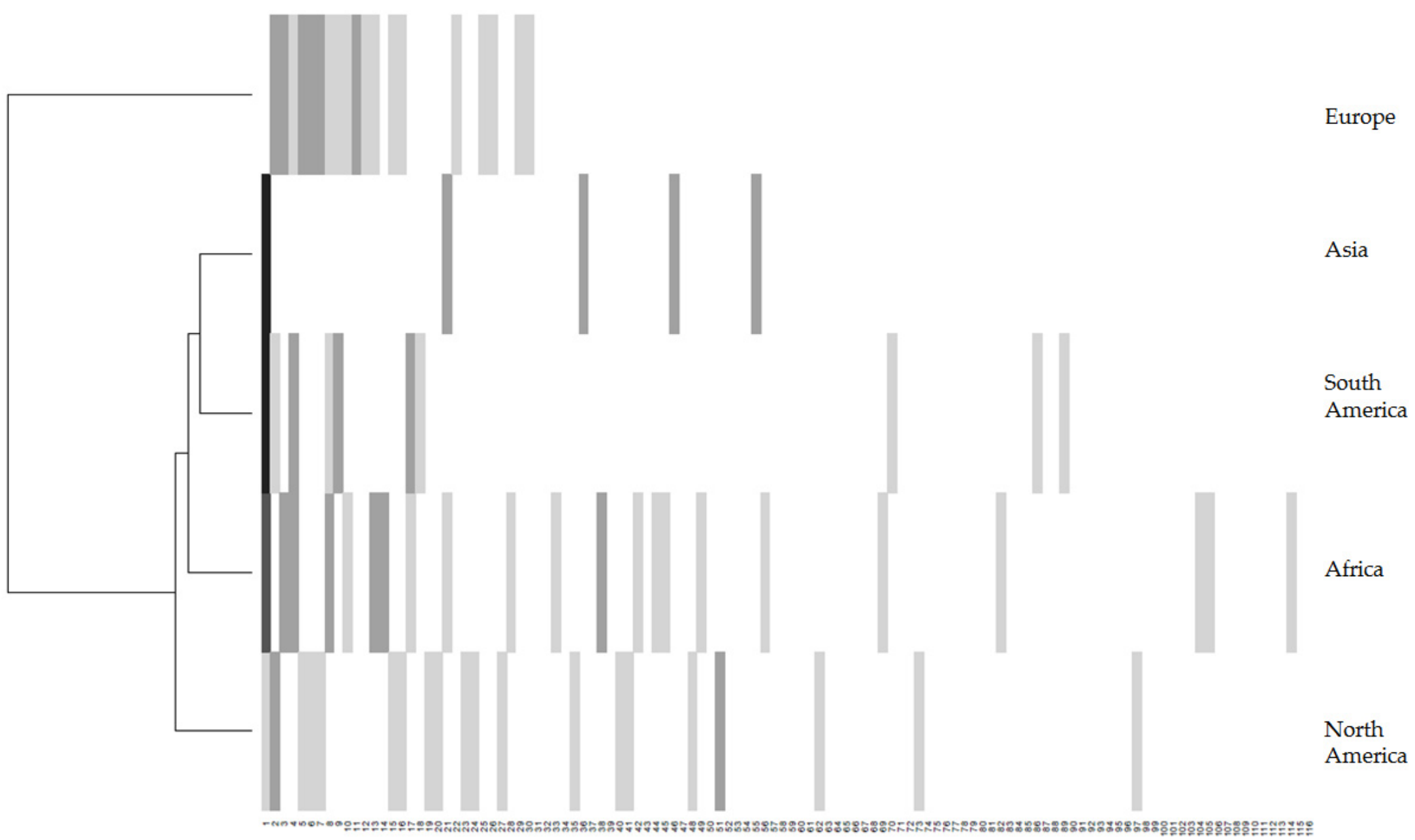

Figure 3. All mycotoxin mixtures quoted in the papers depending on their geographic origin. ( $\square=$ mixtures no cited; $\square=$ mixtures cited between 1 and 3 times; $\square=$ mixtures cited between 3 and 5 times; $\square=$ mixtures cited between 5 and 7 times; $\boldsymbol{\square}=$ mixtures cited between 7 and 9 times; $\mathbf{\square}=$ mixtures cited more than 9 times). Reading from left to right on the $x$-axis: 
1. AFs FUM

. DON ZEA

3. AFs OTA

4. FUM ZEA

5. DON NIV

6. DON T2

7. DON HT2

8. AFs ZEA

. FUM DON

10. FUM OTA

11. DON T2 ZEA

12. T2 HT2

13. BEA ENNs

15. DON ADON NIV

16. DON ADON ZEA

17. AFs FUM ZEA

18. FUM DON ZEA

19. DON ADON

20. DON OTA

21. FUM NIV

22. OTA ZEA

23. OTA CIT

24. DON T2 HT2

25. DON HT2 NIV

26. DON HT2 ZEA

27. DON NIV ZEA

28. FUM ZEA OTA

29. DON ADON HT2 NIV

30. DON T2 HT2 ZEA

31. DON FUS-X

32. ADON ZEA

34. DON ADON HT2

35. DAS T2 HT2

36. AFs FUM DON

37. DON ADON NIV ZEA

38. AFs FUM OTA ZEA

DON ADON T2 HT2 NIV

40. DAS T2
41. DAS HT2

42. T2 NIV

43. T2 ZEA

45. ENNS FUS

46. AFs DON

47. FUM BEA

48. FUM MON

49. OTA NIV

50. DON ADON T2

51. DON DAS HT

52. DON T2 NIV

53. DON HT2 FUS-X

54. DON OTA ZEA

55. AFs FUM NIV

57. DON ADON T2 NIV

58. DON ADON T2 ZEA

59. DON T2 HT2 NIV

60. DON T2 NIV ZEA

60. DON T2 NIV ZEA

62. DON DAS

63. DON $\alpha Z O L$

64. DON ENN

65. NIV HT2

66. NIV FUS-X

67. NIV ZEA

68. ZEA ENNs

69. BEA FUS

70. FUM T2

71. FUM FUS

72. MYC-A ROQ-C

73. DON DAS T2

74. DON NIV FUS-X

75. DON NIV MAS

78. T2 HT2 ZEA

79. NIV FUS-X BEA

80. BEA ENNs FUS
81. BEA ENNs MON

82. AFs OTA DON

83. AFS OTA T2

84. AFs OTA NIV

86. AFs FUM T2

87. AFs DON ZEA

88. FUM DON NIV

89. FUM T2 HT2

90. FUM BEA OTA

91. FUM BEA FUS

92. FUM OTA CIT

93. DON ADON T2 HT2

94. DON ADON HT2 ZEA

95. DON ADON ZEA $\alpha Z O L$

96. DON MAS NIV ZEA

98. DON T2 ZEA $\alpha$ ZOL

99. DON HT2 NIV ZEA

100. DAS T2 HT2 ZEA

101. T2 HT2 MAS ZEA

102. T2 HT2 NIV BEA

103. NIV ZEA BEA ENNs

104. AFs OTA DON ZEA

105. AFS OTA T2 ZEA

106. FUM DON NIV ZEA

107. DON ADON MAS HT2 ZEA

108. DON ADON HT2 NIV ZEA

109. DON ADON HI2 NIV FUS-X

110. DON DAS T2 HT2 ZEA

111. DON MAS T2 HT2 ZEA

112. DON T2 HT2 NIV ZEA

113. MAS T2 HT2 NIV ZEA

114. AFs FUM OTA DON ZEA

115. DON ADON T2 NIV ZEA $\alpha Z O L$

116. DON ADON NIV ZEA $\alpha$ ZOL $\beta Z O L$ 


\section{Toxicological Impact of Mycotoxin Interactions}

As stated previously, toxicological evaluation and therefore regulations are based so far on individual mycotoxin. However, as confirmed by the data analysis presented in the first part of this review, single mycotoxin contamination is not the norm but rather the exception. It is therefore of the utmost importance to evaluate the toxicological impact of mycotoxin combinations to better reflect feed and food contamination and their associated animal and human health risks. In this context, Grenier and Oswald [6] reviewed in vivo experiments until 2010, in which laboratory and farm animals were exposed to a combination of mycotoxins, and described the type of observed interactions. Since 2011, only few in vivo studies have been published. In the framework of this review, we focused on in vitro experiments published between 1980 and 2015. Indeed, even if cell cultures have many limitations such as immortalization, limited survival or metabolic imbalance, in vitro models are more and more used for understanding the mechanisms of mycotoxin action and their mixtures, especially toxicity on cell-specific function [152]. Among the 58 analyzed articles, 50\% were published during the last five years showing the interest of this approach as an alternative of interest to animal models. In this context, in vitro studies become embedded in national and international legislation regulating the use of animals in scientific procedures in order to encourage and develop the principles of the 3Rs (Replacement, Reduction, and Refinement) as a framework for humane animal research.

Most of the selected publications concern the effect of binary mixtures. Indeed, among the 93 studied mycotoxin mixtures, $70 \%$ corresponded to binary mixtures, $24 \%$ to ternary mixtures, and $6 \%$ were quaternary or quinary mixtures. Furthermore, the main studied mixtures were OTA+CIT, DON+NIV, DON+T2, OTA+AFB1, and OTA+FB1 found in $28 \%, 14 \%, 12 \%, 10 \%$, and $9 \%$ of the articles, respectively. Another observation corresponds to the fact that mixtures involving fusariotoxins were the most studied, representing about $70 \%$ of all the analyzed mixtures, with $50 \%$ involving exclusively fusariotoxins and $22 \%$ are formed with OTA.

Concerning cell models, $43 \%$ of the authors used, inter alia, cells from human origin, $26 \%$ porcine models, $19 \%$ murine models, and more marginally monkey, bovine, fish, turkey or/and even yeast, which is a simple model to examine the immediate effects of mycotoxins on growth inhibition or $\mathrm{CO}_{2}$ production for example (Figure 4a). Overall, more than 30 different cell lines were used among the 58 articles studied, and most of these cells came from kidney, blood, intestine, and liver (Figure 4b). More particularly, Caco-2 (human epithelial colorectal adenocarcinoma cells), PK15 no copyright permission needed as we created this figure (porcine hepatocellular carcinoma cells), Vero (monkey renal proximal tubular epithelial cells), and HepG2 (human kidney epithelial cells) were the most used cell models as they were reported in $8,8,7$, and 5 articles, respectively. This is linked to the fact that these cell models correspond to major organs targeted by mycotoxins [153].

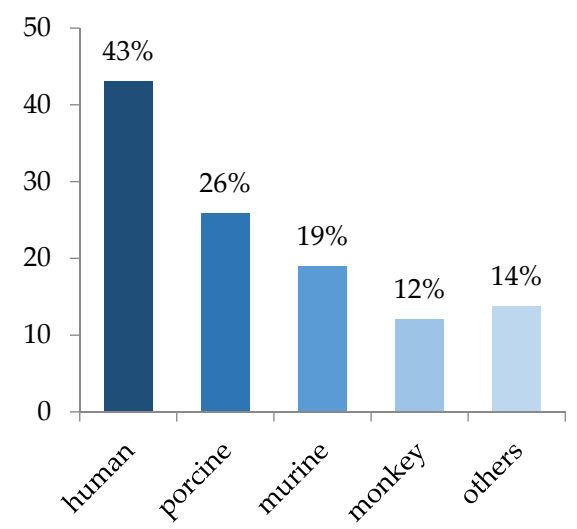

(a)

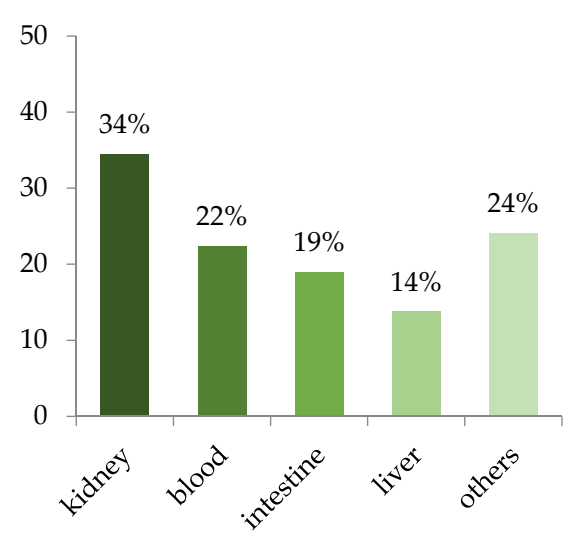

(b)

Figure 4. Distribution of cell models used depending on (a) species and (b) organs. Data are compiled from the 58 selected articles. References: [9,154-210]. 
Regarding the studied parameters, cell viability was the main endpoint used by the authors (in $64 \%$ of the studies), followed by cell apoptosis or/and necrosis $(19 \%)$, DNA damage $(17 \%)$ and oxidative damage $(16 \%)$. Some authors were also interested in macromolecule synthesis (RNA, DNA, proteins), or immunotoxicity parameters. Moreover, all these tests are performed between 0 and $72 \mathrm{~h}$ (acute exposure), except in the work of Ficheux et al. [166], in which mycotoxin interactions were studied during 14 days (chronic exposure). In particular, for cell viability, studies were mostly carried out on $24 \mathrm{~h}$ and/or $48 \mathrm{~h}$, with the most commonly used being the tetrazolium reduction assays. Different tetrazolium reduction assays exist, based on similar principles, such as MTT 3-(4,5-dimethylthiazol-2-yl)-2,5-diphenyltetrazolium bromide, MTS 3-[4,5-dimethylthiazol-2-yl]-5-(3-carboxymethoxyphenyl)-2-(4-sulfophenyl)-2 $\mathrm{H}$-tetrazolium and WST-1 (2-(4-iodophenyl)-3-(4-nitrophenyl)-5-(2,4-disulfophenyl)-2H-tetrazolium). The neutral red and trypan blue assays are two other methods commonly used to evaluate cell viability. Some authors assessed mycotoxin toxicological effects individually and/or combined on cell proliferation using two or three cell viability assays (tetrazolium reduction, neutral red and trypan blue assays) and results were similar from one method to the other $[9,155,160,185,197]$.

In the present review, we decided to focus on the in vitro effects of fusariotoxin mixtures on cell viability using mammalian cell models (Table 2). Concerning mycotoxin mixtures involving OTA, a review about their in vitro and in vivo combined effects was recently published [211].

To better understand the conclusions presented by the authors about the in vitro effects of fusariotoxin mixtures, the main types of interactions between mycotoxins, as well as mathematical models for characterizing these interactions, are described hereafter.

\subsection{Characterization of the Different Interactions Between Mycotoxins}

Mycotoxin interactions can be classified in three main different categories: antagonistic, additive, and synergistic. Depending on the authors, more categories may be distinguished, namely potentiation and less-than-additive, often classified in synergistic and antagonistic effects, respectively. Figure 5 illustrates the possible different interactions of mycotoxins with the example of cell viability measure.

Additivity is mentioned when the effect of the combination could be calculated as the sum of the individual effects of the two studied toxins (Figure 5a). Thus, additivity is a priori an absence of interaction.

Synergism is observed when the effect of the mycotoxin combination is greater than expected in comparison to the sum of the individual effects of the two studied mycotoxins (Figure 5b). In the case when one or both of the mycotoxins does not induce effect whereas the combination induces a significant effect, one can speak of potentiation (Figure 5c). However, very few studies use this term to categorize the effect, and most of them use synergism.

Antagonism is cited when the effect of the mycotoxin combination is lower than expected from the sum of the individual effects of the two studied mycotoxins (Figure $5 \mathrm{~d}$ ). If the effect of the mycotoxin combination mainly reflected the effect of the most toxic mycotoxin, without additional effect of the other mycotoxin, the term "less-than-additive" may be used. 
Table 2. In vitro interactions between fusariotoxins on cell viability.

\begin{tabular}{|c|c|c|c|c|c|}
\hline Mycotoxin Couples/Cells & Doses $(\mu \mathrm{M})$ & Exposure & & Toxicological Effect & References \\
\hline \multicolumn{6}{|c|}{ Interaction between TCT } \\
\hline DON+15-ADON & DON: $0.25-4$ & \multirow{2}{*}{$48 \mathrm{~h}$} & Synergistic & at low inhibitory concentration levels $\left(\mathrm{IC}_{10,20,30}\right)$ & \multirow{2}{*}{ [155] } \\
\hline $\begin{array}{l}\text { Human epithelial colorectal } \\
\text { adenocarcinoma cells: Caco-2 }\end{array}$ & 15-ADON: $0.25-4$ & & Additive & at medium inhibit concentration levels $\left(\mathrm{IC}_{40,50}\right)$ & \\
\hline $\begin{array}{l}\text { DON+15-ADON } \\
\text { Intestinal porcine epithelial cells } \\
\text { (ileum + jejunum): IPEC-1 }\end{array}$ & $\begin{array}{c}\text { DON: } 0.2-15 \\
\text { 15-ADON: } 0.2-15\end{array}$ & $24 \mathrm{~h}$ & Synergistic & from $\mathrm{IC}_{10}$ to $\mathrm{IC}_{80}$ & [154] \\
\hline $\begin{array}{l}\text { DON+3-ADON } \\
\text { Human epithelial colorectal } \\
\text { adenocarcinoma cells: Caco-2 }\end{array}$ & $\begin{array}{c}\text { DON: } 0.25-4 \\
\text { 3-ADON: } 0.42-6.67\end{array}$ & $48 \mathrm{~h}$ & $\begin{array}{l}\text { Synergistic } \\
\text { Additive }\end{array}$ & $\begin{array}{l}\text { at low and medium inhibitory concentration levels }\left(\mathrm{IC}_{10,20,30,40}\right) \\
\text { at the } 50 \% \text { growth inhibition level }\left(\mathrm{IC}_{50}\right)\end{array}$ & [155] \\
\hline $\begin{array}{l}\text { DON+3-ADON } \\
\text { Intestinal porcine epithelial cells } \\
\text { (ileum + jejunum): IPEC-1 }\end{array}$ & $\begin{array}{c}\text { DON: } 0.2-15 \\
\text { 3-ADON: } 2-150\end{array}$ & $24 \mathrm{~h}$ & $\begin{array}{l}\text { Antagonistic } \\
\text { Additive } \\
\text { Synergistic }\end{array}$ & $\begin{array}{l}\text { at low inhibitory concentration levels }\left(\mathrm{IC}_{10}-\mathrm{IC}_{30}\right) \\
\text { at medium inhibitory concentration levels }\left(\mathrm{IC}_{30}-\mathrm{IC}_{60}\right) \\
\text { at high inhibitory concentration levels }\left(\mathrm{IC}_{60}-\mathrm{IC}_{80}\right)\end{array}$ & [154] \\
\hline $\begin{array}{l}\text { 15-ADON+3-ADON } \\
\text { Human epithelial colorectal } \\
\text { adenocarcinoma cells: Caco-2 }\end{array}$ & $\begin{array}{l}\text { 15-ADON: } 0.25-4 \\
\text { 3-ADON: } 0.42-6.67\end{array}$ & $48 \mathrm{~h}$ & $\begin{array}{l}\text { Synergistic } \\
\text { Additive }\end{array}$ & $\begin{array}{l}\text { at low cytotoxicity levels }\left(\mathrm{IC}_{10,20,30}\right) \\
\text { at medium inhibitory concentration levels }\left(\mathrm{IC}_{40,50}\right)\end{array}$ & [155] \\
\hline $\begin{array}{l}\text { 15-ADON+3-ADON } \\
\text { Intestinal porcine epithelial cells } \\
\text { (ileum + jejunum): IPEC-1 }\end{array}$ & $\begin{array}{l}\text { 15-ADON: } 0.2-15 \\
\text { 3-ADON: 2-150 }\end{array}$ & $24 \mathrm{~h}$ & Synergistic & at all cytotoxicity levels $\left(\mathrm{IC}_{10}-\mathrm{IC}_{80}\right)$ & [154] \\
\hline $\begin{array}{l}\text { DON+15-ADON+3-ADON } \\
\text { Human epithelial colorectal } \\
\text { adenocarcinoma cells: Caco-2 }\end{array}$ & $\begin{array}{c}\text { DON: } 0.25-4 \\
\text { 15-ADON: } 0.25-4 \\
\text { 3-ADON: } 0.42-6.67\end{array}$ & $48 \mathrm{~h}$ & $\begin{array}{l}\text { Synergistic } \\
\text { Additive } \\
\text { Antagonistic }\end{array}$ & $\begin{array}{l}\text { at low cytotoxicity levels }\left(\mathrm{IC}_{10,20,30}\right) \\
\text { at the } 40 \% \text { growth inhibition level }\left(\mathrm{IC}_{40}\right) \\
\text { from the } 50 \% \text { growth inhibition level }\left(\mathrm{IC}_{50}\right)\end{array}$ & [155] \\
\hline $\begin{array}{l}\text { DON+NIV } \\
\text { Murine monocyte macrophage } \\
\text { cells: J774A.1 }\end{array}$ & $\begin{array}{l}\text { DON: } 10-100 \\
\text { NIV: } 10-100\end{array}$ & $24 \mathrm{~h}, 48 \mathrm{~h}$ and $72 \mathrm{~h}$ & Additive & at $50 \%$ growth inhibition level $\left(\mathrm{IC}_{50}\right)$ & [194] \\
\hline $\begin{array}{l}\text { DON+NIV } \\
\text { Intestinal porcine epithelial cells } \\
\text { (jejunum): IPEC-J2 }\end{array}$ & $\begin{array}{l}\text { DON: } 0.5-2 \\
\text { NIV: } 0.5-2\end{array}$ & $48 \mathrm{~h}$ & $\begin{array}{l}\text { Antagonistic } \\
\text { Synergistic }\end{array}$ & $\begin{array}{l}\text { at the lowest dose } \\
\text { at the highest dose }\end{array}$ & [209] \\
\hline $\begin{array}{l}\text { DON+NIV } \\
\text { Human epithelial colorectal } \\
\text { adenocarcinoma cells: Caco-2 }\end{array}$ & $\begin{array}{l}\text { DON: } 0.25-4 \\
\text { NIV: } 0.2-3.2\end{array}$ & $48 \mathrm{~h}$ & Synergistic & at all cytotoxicity levels (from $\mathrm{IC}_{10}$ to $\mathrm{IC}_{50}$ ) & [155] \\
\hline $\begin{array}{l}\text { DON+NIV } \\
\text { Intestinal porcine epithelial cells } \\
\text { (ileum + jejunum): IPEC-1 }\end{array}$ & $\begin{array}{l}\text { DON: } 0.2-15 \\
\text { NIV: } 0.2-15\end{array}$ & $24 \mathrm{~h}$ & Synergistic & at all cytotoxicity levels (from $\mathrm{IC}_{10}$ to $\mathrm{IC}_{80}$ ) & [154] \\
\hline $\begin{array}{l}\text { DON+FX } \\
\text { Human epithelial colorectal } \\
\text { adenocarcinoma cells: Caco-2 }\end{array}$ & $\begin{array}{l}\text { DON: } 0.25-4 \\
\text { FX: } 7.5-120\end{array}$ & $48 \mathrm{~h}$ & Synergistic & at all cytotoxicity levels (from $\mathrm{IC}_{10}$ to $\mathrm{IC}_{50}$ ) & [155] \\
\hline
\end{tabular}


Table 2. Cont

\begin{tabular}{|c|c|c|c|c|c|}
\hline Mycotoxin Couples/Cells & Doses $(\mu \mathbf{M})$ & Exposure & & Toxicological Effect & References \\
\hline $\begin{array}{l}\text { DON+FX } \\
\text { Intestinal porcine epithelial cells } \\
\text { (ileum + jejunum): IPEC-1 }\end{array}$ & $\begin{array}{l}\text { DON: } 0.2-15 \\
\text { FX: } 0.12-9\end{array}$ & $24 \mathrm{~h}$ & Antagonistic & at all inhibitory concentration levels $\left(\mathrm{IC}_{10}-\mathrm{IC}_{80}\right)$ & [154] \\
\hline $\begin{array}{l}\text { NIV+FX } \\
\text { Human epithelial colorectal } \\
\text { adenocarcinoma cells: Caco-2 }\end{array}$ & $\begin{array}{l}\text { NIV: } 0.2-3.2 \\
\text { FX: } 7.5-120\end{array}$ & $48 \mathrm{~h}$ & $\begin{array}{l}\text { Synergistic } \\
\text { Additive }\end{array}$ & $\begin{array}{l}\text { at low cytotoxicity levels }\left(\mathrm{IC}_{10,20}\right) \\
\text { at medium cytotoxicity levels }\left(\mathrm{IC}_{30,40,50}\right)\end{array}$ & [155] \\
\hline $\begin{array}{l}\text { NIV+FX } \\
\text { Intestinal porcine epithelial cells } \\
\text { (ileum + jejunum): IPEC-1 }\end{array}$ & $\begin{array}{l}\text { NIV: } 0.2-15 \\
\text { FX: } 0.16-12\end{array}$ & $24 \mathrm{~h}$ & Additive & at all cytotoxicity levels $\left(\mathrm{IC}_{10}-\mathrm{IC}_{80}\right)$ & [154] \\
\hline $\begin{array}{l}\text { DON+NIV+FX } \\
\text { Human epithelial colorectal } \\
\text { adenocarcinoma cells: Caco-2 }\end{array}$ & $\begin{array}{l}\text { DON: } 0.25-4 \\
\text { NIV: } 0.2-3.2 \\
\text { FX: } 7.5-120\end{array}$ & $48 \mathrm{~h}$ & $\begin{array}{l}\text { Antagonistic } \\
\text { Additive }\end{array}$ & $\begin{array}{l}\text { at low cytotoxicity levels }\left(\mathrm{IC}_{10,20}\right) \\
\text { at medium cytotoxicity levels }\left(\mathrm{IC}_{30,40,50}\right)\end{array}$ & [155] \\
\hline $\begin{array}{l}\text { DON+T2 } \\
\text { Chinese hamster ovary cells: } \\
\text { CHO-K1 }\end{array}$ & $\begin{array}{l}\text { DON: } 0.25-4 \\
\text { T2: } 0.006-0.1\end{array}$ & $24 \mathrm{~h}, 48 \mathrm{~h}$ and $72 \mathrm{~h}$ & Antagonistic & & [197] \\
\hline $\begin{array}{l}\text { DON+T2 } \\
\text { Monkey kidney epithelial cells: } \\
\text { Vero }\end{array}$ & $\begin{array}{l}\text { DON: } 0.25-8 \\
\text { T2: } 0.001-0.05\end{array}$ & $24 \mathrm{~h}, 48 \mathrm{~h}$ and $72 \mathrm{~h}$ & Antagonistic & & [198] \\
\hline $\begin{array}{l}\text { DON+T2 } \\
\text { Hematopoietic progenitors: } \\
\text { CFU-GM }\end{array}$ & $\begin{array}{c}\text { DON: } 0.04-0.1 \\
\text { T2: } 0.0005-0.0016\end{array}$ & 14 days & Additive & & [166] \\
\hline & & Interactio & en TCT and oth & ariotoxins & \\
\hline $\begin{array}{l}\text { DON+BEA } \\
\text { Chinese hamster ovary cells: } \\
\text { CHO-K1 }\end{array}$ & $\begin{array}{l}\text { DON: } 0.25-4 \\
\text { BEA: } 0.78-12.5\end{array}$ & $24 \mathrm{~h}, 48 \mathrm{~h}$ and $72 \mathrm{~h}$ & Antagonistic & & [197] \\
\hline $\begin{array}{l}\text { DON+BEA } \\
\text { Monkey kidney epithelial cells: } \\
\text { Vero }\end{array}$ & $\begin{array}{l}\text { DON: } 0.25-8 \\
\text { BEA: } 0.78-25\end{array}$ & $24 \mathrm{~h}, 48 \mathrm{~h}$ and $72 \mathrm{~h}$ & Antagonistic & & [198] \\
\hline $\begin{array}{l}\text { DON+BEA } \\
\text { Hematopoietic progenitors: } \\
\text { CFU-GM }\end{array}$ & $\begin{array}{l}\text { DON: } 0.04-0.1 \\
\text { BEA: } 0.064-3.2\end{array}$ & 14 days & Synergistic & & [166] \\
\hline $\begin{array}{l}\text { T2+BEA } \\
\text { Chinese hamster ovary cells: } \\
\text { CHO-K1 }\end{array}$ & $\begin{array}{l}\text { T2: } 0.006-0.1 \\
\text { BEA: } 0.78-12.5\end{array}$ & $24 \mathrm{~h}, 48 \mathrm{~h}$ and $72 \mathrm{~h}$ & Synergistic & & [197] \\
\hline $\begin{array}{l}\text { T2+BEA } \\
\text { Monkey kidney epithelial cells: } \\
\text { Vero }\end{array}$ & $\begin{array}{l}\text { T2: } 0.001-0.05 \\
\text { BEA: } 0.78-25\end{array}$ & $24 \mathrm{~h}, 48 \mathrm{~h}$ and $72 \mathrm{~h}$ & Antagonistic & & [198] \\
\hline $\begin{array}{l}\text { DON+FB1 } \\
\text { Human epithelial colorectal } \\
\text { adenocarcinoma cells: Caco-2 }\end{array}$ & $\begin{array}{l}\text { DON: } 4-20 \\
\text { FB1: } 10\end{array}$ & $72 \mathrm{~h}$ & Additive & & [187] \\
\hline $\begin{array}{l}\text { DON+FB1 } \\
\text { Hematopoietic progenitors: } \\
\text { CFU-GM }\end{array}$ & $\begin{array}{l}\text { DON: } 0.04-0.1 \\
\text { FB1: } 0.5-2\end{array}$ & 14 days & Antagonistic & & [166] \\
\hline
\end{tabular}


Table 2. Cont

\begin{tabular}{|c|c|c|c|c|c|}
\hline Mycotoxin Couples/Cells & Doses $(\mu \mathbf{M})$ & Exposure & & Toxicological Effect & References \\
\hline $\begin{array}{l}\text { DON+FB1 } \\
\text { Intestinal porcine epithelial cells } \\
\text { (jejunum): IPEC-J2 }\end{array}$ & $\begin{array}{l}\text { DON: } 0.5-2 \\
\text { FB1: } 20-40\end{array}$ & $48 \mathrm{~h}$ & $\begin{array}{l}\text { Antagonistic } \\
\text { Synergistic }\end{array}$ & $\begin{array}{l}\text { at the lowest dose } \\
\text { at the highest dose }\end{array}$ & [209] \\
\hline $\begin{array}{l}\text { NIV+FB1 } \\
\text { Intestinal porcine epithelial cells } \\
\text { (jejunum): IPEC-J2 }\end{array}$ & $\begin{array}{l}\text { NIV: } 0.5-2 \\
\text { FB1: } 20-40\end{array}$ & $48 \mathrm{~h}$ & $\begin{array}{l}\text { Antagonistic } \\
\text { Synergistic }\end{array}$ & $\begin{array}{l}\text { at the lowest dose } \\
\text { at the highest dose }\end{array}$ & [209] \\
\hline $\begin{array}{l}\text { DON+ZEA } \\
\text { Human epithelial colorectal } \\
\text { adenocarcinoma cells: Caco-2 }\end{array}$ & $\begin{array}{l}\text { DON: } 10-20 \\
\text { ZEA: } 10-20\end{array}$ & $72 \mathrm{~h}$ & Additive & & [187] \\
\hline $\begin{array}{l}\text { DON+ZEA } \\
\text { Hematopoietic progenitors: } \\
\text { CFU-GM }\end{array}$ & $\begin{array}{l}\text { DON: } 0.04-0.1 \\
\text { ZEA: } 0.2-10\end{array}$ & 14 days & Additive & & [166] \\
\hline $\begin{array}{l}\text { DON+ZEA } \\
\text { Intestinal porcine epithelial cells } \\
\text { (jejunum): IPEC-J2 }\end{array}$ & $\begin{array}{l}\text { DON: } 0.5-2 \\
\text { ZEA: } 10-40\end{array}$ & $48 \mathrm{~h}$ & $\begin{array}{l}\text { Antagonistic } \\
\text { Synergistic }\end{array}$ & $\begin{array}{l}\text { at the lowest dose } \\
\text { at the highest dose }\end{array}$ & [209] \\
\hline $\begin{array}{l}\text { DON+ZEA } \\
\text { Human colon carcinoma cells: } \\
\text { HCT116 }\end{array}$ & $\begin{array}{c}\text { DON: } 100 \\
\text { ZEA: } 40\end{array}$ & $24 \mathrm{~h}$ & Antagonistic & & [156] \\
\hline $\begin{array}{l}\text { NIV+ZEA } \\
\text { Intestinal porcine epithelial cells } \\
\text { (jejunum): IPEC-J2 }\end{array}$ & $\begin{array}{l}\text { NIV: } 0.5-2 \\
\text { ZEA: } 10-40\end{array}$ & $48 \mathrm{~h}$ & $\begin{array}{l}\text { Antagonistic } \\
\text { Synergistic }\end{array}$ & $\begin{array}{l}\text { at the lowest dose } \\
\text { at the highest dose }\end{array}$ & [209] \\
\hline $\begin{array}{l}\text { T2+ZEA } \\
\text { Hematopoietic progenitors: } \\
\text { CFU-GM }\end{array}$ & $\begin{array}{l}\text { T2: } 0.0005-0.0016 \\
\text { ZEA: } 0.2-10\end{array}$ & 14 days & Additive & & [166] \\
\hline $\begin{array}{l}\text { T2+ZEA } \\
\text { Monkey kidney epithelial cells: } \\
\text { Vero }\end{array}$ & $\begin{array}{c}\text { T2: } 0.025-0.1 \\
\text { ZEA: } 0.025-0.1\end{array}$ & $24 \mathrm{~h}$ & Additive & & [158] \\
\hline $\begin{array}{l}\text { DON+T2+BEA } \\
\text { Chinese hamster ovary cells: } \\
\text { CHO-K1 }\end{array}$ & $\begin{array}{c}\text { DON: } 0.25-4 \\
\text { T2: } 0.006-0.1 \\
\text { BEA: } 0.78-12.5\end{array}$ & $24 \mathrm{~h}, 48 \mathrm{~h}$, and $72 \mathrm{~h}$ & Synergistic & & [197] \\
\hline $\begin{array}{l}\text { DON+T2+BEA } \\
\text { Monkey kidney epithelial cells: } \\
\text { Vero }\end{array}$ & $\begin{array}{l}\text { DON: } 0.25-8 \\
\text { T2: } 0.001-0.05 \\
\text { BEA: } 0.78-25\end{array}$ & $24 \mathrm{~h}, 48 \mathrm{~h}$, and $72 \mathrm{~h}$ & Antagonistic & & [198] \\
\hline $\begin{array}{l}\text { DON+NIV+ZEA } \\
\text { Intestinal porcine epithelial cells } \\
\text { (jejunum): IPEC-J2 }\end{array}$ & $\begin{array}{l}\text { DON: } 0.5-2 \\
\text { NIV: } 0.5-2 \\
\text { ZEA: } 10-40\end{array}$ & $48 \mathrm{~h}$ & $\begin{array}{l}\text { Antagonistic } \\
\text { Synergistic }\end{array}$ & $\begin{array}{l}\text { at the lowest dose } \\
\text { at the highest dose }\end{array}$ & [209] \\
\hline
\end{tabular}


Table 2. Cont

\begin{tabular}{|c|c|c|c|c|c|}
\hline Mycotoxin Couples/Cells & Doses $(\mu \mathbf{M})$ & Exposure & & Toxicological Effect & References \\
\hline $\mathrm{DON}+\mathrm{NIV}+\mathrm{FB1}$ & $\begin{array}{l}\text { DON: } 0.5-2 \\
\text { NIV: } 0.5-2\end{array}$ & \multirow[t]{2}{*}{$48 \mathrm{~h}$} & Antagonistic & at the lowest dose & \multirow[t]{2}{*}{ [209] } \\
\hline $\begin{array}{l}\text { Intestinal porcine epithelial cells } \\
\text { (jejunum): IPEC-J2 }\end{array}$ & FB1: $20-40$ & & Synergistic & at the highest dose & \\
\hline $\begin{array}{l}\text { DON+ZEA+FB1 } \\
\text { Human epithelial colorectal } \\
\text { adenocarcinoma cells: Caco-2 }\end{array}$ & $\begin{array}{l}\text { DON: } 10-20 \\
\text { ZEA: } 10-20 \\
\text { FB1: } 10\end{array}$ & $72 \mathrm{~h}$ & \multicolumn{2}{|l|}{ Additive } & [187] \\
\hline $\begin{array}{l}\text { DON+ZEA+FB1 } \\
\text { Intestinal porcine epithelial cells } \\
\text { (jejunum): IPEC-J2 }\end{array}$ & $\begin{array}{l}\text { DON: } 0.5-2 Z \\
\text { EA: } 10-40 \\
\text { FB1: } 20-40\end{array}$ & $48 \mathrm{~h}$ & $\begin{array}{l}\text { Antagonistic } \\
\text { Synergistic }\end{array}$ & $\begin{array}{l}\text { at the lowest dose } \\
\text { at the highest dose }\end{array}$ & [209] \\
\hline $\begin{array}{l}\text { NIV+ZEA+FB1 } \\
\text { Intestinal porcine epithelial cells } \\
\text { (jejunum): IPEC-J2 }\end{array}$ & $\begin{array}{l}\text { NIV: } 0.5-2 \\
\text { ZEA: } 10-40 \\
\text { FB1: } 20-40\end{array}$ & $48 \mathrm{~h}$ & $\begin{array}{l}\text { Antagonistic } \\
\text { Synergistic }\end{array}$ & $\begin{array}{l}\text { at the lowest dose } \\
\text { at the highest dose }\end{array}$ & [209] \\
\hline $\begin{array}{l}\text { DON+NIV+ZEA+FB1 } \\
\text { Intestinal porcine epithelial cells } \\
\text { (jejunum): IPEC-J2 }\end{array}$ & $\begin{array}{l}\text { DON: } 0.5-2 \\
\text { NIV: } 0.5-2 \\
\text { ZEA: } 10-40 \\
\text { FB1: } 20-40\end{array}$ & $48 \mathrm{~h}$ & $\begin{array}{l}\text { Antagonistic } \\
\text { Synergistic }\end{array}$ & $\begin{array}{l}\text { at the lowest dose } \\
\text { at the highest dose }\end{array}$ & [209] \\
\hline \multicolumn{6}{|c|}{ Interaction between other fusariotoxins } \\
\hline \multirow{2}{*}{$\begin{array}{l}\text { ZEA }+\alpha-\text { ZOL } \\
\text { Human hepatocellular } \\
\text { carcinoma cells: HepG2 }\end{array}$} & \multirow[b]{2}{*}{$\begin{array}{l}\text { ZEA: 0.5-50 } \\
\alpha \text {-ZOL: } 1-100\end{array}$} & $24 \mathrm{~h}$ and $72 \mathrm{~h}$ & Antagonistic & at all cytotoxicity levels (from $\mathrm{IC}_{10}$ to $\mathrm{IC}_{90}$ ) & \multirow[b]{2}{*}{ [208] } \\
\hline & & $48 \mathrm{~h}$ & $\begin{array}{l}\text { Antagonistic } \\
\text { Additive } \\
\text { Synergistic }\end{array}$ & $\begin{array}{l}\text { at } \mathrm{IC}_{10,20,30,40} \\
\text { at } \mathrm{IC}_{50,60,70} \\
\text { at } \mathrm{IC}_{80,90}\end{array}$ & \\
\hline \multirow{2}{*}{$\begin{array}{l}\text { ZEA }+\alpha-Z O L \\
\text { Chinese hamster ovary cells: } \\
\text { CHO-K1 }\end{array}$} & \multirow[t]{2}{*}{ 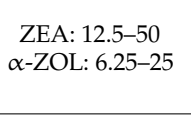 } & $24 \mathrm{~h}$ & $\begin{array}{l}\text { Synergistic } \\
\text { Additive }\end{array}$ & $\begin{array}{l}\text { at low cytotoxicity level }\left(\mathrm{IC}_{25}\right) \\
\text { at medium and high cytotoxicity levels (from } \mathrm{IC}_{50} \text { to } \mathrm{IC}_{90} \text { ) }\end{array}$ & \multirow[t]{2}{*}{ [204] } \\
\hline & & $48 \mathrm{~h}$ and $72 \mathrm{~h}$ & Additive & at all cytotoxicity levels (from $\mathrm{IC}_{25}$ to $\mathrm{IC}_{90}$ ) & \\
\hline $\begin{array}{l}\text { ZEA+ } \beta-Z O L \\
\text { Chinese hamster ovary cells: } \\
\text { CHO-K1 }\end{array}$ & $\begin{array}{l}\text { ZEA: } 12.5-50 \\
\beta \text {-ZOL: } 6.25-25\end{array}$ & $24 \mathrm{~h}, 48 \mathrm{~h}$ and $72 \mathrm{~h}$ & Additive & at all cytotoxicity levels (from $\mathrm{IC}_{25}$ to $\mathrm{IC}_{90}$ ) & [204] \\
\hline \multirow{4}{*}{$\begin{array}{l}\alpha-\mathrm{ZOL}+\beta-\mathrm{ZOL} \\
\text { Chinese hamster ovary cells: } \\
\text { CHO-K1 }\end{array}$} & \multirow{2}{*}{$\alpha$-ZOL: $6.25-25$} & $24 \mathrm{~h}$ & Additive & at all cytotoxicity levels $\left(\mathrm{IC}_{25}, 50,75,90\right)$ & \multirow{4}{*}{ [204] } \\
\hline & & \multirow{2}{*}{$48 \mathrm{~h}$} & Antagonistic & at low and medium cytotoxicity levels $\left(\mathrm{IC}_{25,50}\right)$ & \\
\hline & \multirow{2}{*}{$\beta$-ZOL: $6.25-25$} & & Additive & at high cytotoxicity levels $\left(\mathrm{IC}_{75,90}\right)$ & \\
\hline & & $72 \mathrm{~h}$ & $\begin{array}{l}\text { Additive } \\
\text { Antagonistic }\end{array}$ & $\begin{array}{l}\text { at low and high cytotoxicity levels }\left(\mathrm{IC}_{25,75,90}\right) \\
\text { at medium cytotoxicity level }\left(\mathrm{IC}_{50}\right)\end{array}$ & \\
\hline \multirow{2}{*}{$\mathrm{ZEA}+\alpha-\mathrm{ZOL}+\beta-\mathrm{ZOL}$} & \multirow{2}{*}{ ZEA: $12.5-5$} & \multirow{2}{*}{$24 \mathrm{~h}$ and $48 \mathrm{~h}$} & Antagonistic & at low and medium cytotoxicity levels $\left(\mathrm{IC}_{25,50}\right)$ & \multirow{2}{*}{ [204] } \\
\hline & & & Synergistic & at high cytotoxicity levels $\left(\mathrm{IC}_{75,90}\right)$ & \\
\hline
\end{tabular}


Table 2. Cont

\begin{tabular}{|c|c|c|c|c|c|}
\hline Mycotoxin Couples/Cells & Doses $(\mu \mathrm{M})$ & Exposure & & Toxicological Effect & References \\
\hline $\begin{array}{l}\text { Chinese hamster ovary cells: } \\
\text { CHO-K1 }\end{array}$ & $\begin{array}{l}\alpha \text {-ZOL: } 6.25-25 \\
\beta \text {-ZOL: } 6.25-25\end{array}$ & $72 \mathrm{~h}$ & $\begin{array}{l}\text { Antagonistic } \\
\text { Synergistic }\end{array}$ & $\begin{array}{l}\text { at low cytotoxicity level }\left(\mathrm{IC}_{25}\right) \\
\text { at medium and high cytotoxicity levels }\left(\mathrm{IC}_{50,75,90}\right)\end{array}$ & \\
\hline $\begin{array}{l}\text { ZEA+FB1 } \\
\text { Human epithelial colorectal } \\
\text { adenocarcinoma cells: Caco-2 }\end{array}$ & $\begin{array}{l}\text { ZEA: } 5-20 \\
\text { FB1: } 10\end{array}$ & $72 \mathrm{~h}$ & Antagonistic & & [187] \\
\hline $\begin{array}{l}\text { ZEA+FB1 } \\
\text { Intestinal porcine epithelial cells } \\
\text { (jejunum): IPEC-J2 }\end{array}$ & $\begin{array}{l}\text { ZEA: } 10-40 \\
\text { FB1: } 20-40\end{array}$ & $48 \mathrm{~h}$ & $\begin{array}{l}\text { Antagonistic } \\
\text { Synergistic }\end{array}$ & $\begin{array}{l}\text { at the lowest dose } \\
\text { at the highest dose }\end{array}$ & [209] \\
\hline $\begin{array}{l}\text { ZEA+FB1 } \\
\text { Human epithelial colorectal } \\
\text { adenocarcinomia cells: Caco-2 }\end{array}$ & $\begin{array}{l}\text { ZEA: } 10 \\
\text { FB1: } 10\end{array}$ & $72 \mathrm{~h}$ & Antagonistic & & [186] \\
\hline $\begin{array}{l}\text { BEA+FB1 } \\
\text { Porcine renal proximal tubular } \\
\text { epithelial cells: PK15 }\end{array}$ & $\begin{array}{l}\text { BEA: } 0.064-6.4 \mu \mathrm{M} \\
\text { FB1: } 0.069-6.9 \mu \mathrm{M}\end{array}$ & $24 \mathrm{~h}$ & $\begin{array}{l}\text { Additive } \\
\text { Antagonistic }\end{array}$ & $\begin{array}{l}\text { at low doses } \\
\text { at the highest dose }\end{array}$ & [179] \\
\hline $\begin{array}{l}\text { BEA+ENB } \\
\text { Hematopoietic progenitors: } \\
\text { CFU-GM }\end{array}$ & $\begin{array}{l}\text { BEA: } 0.064-3.2 \\
\text { ENB: } 2-6\end{array}$ & 14 days & Additive & & [166] \\
\hline $\begin{array}{l}\text { ENA+ENA }_{1} \\
\text { Chinese hamster ovary cells: } \\
\text { CHO-K1 }\end{array}$ & $\begin{array}{l}\text { ENA: } 0.365-5 \\
\text { ENA }_{1}: 0.625-5\end{array}$ & $24 \mathrm{~h}$ & $\begin{array}{l}\text { Synergistic } \\
\text { Additive }\end{array}$ & $\begin{array}{l}\text { at low cytotoxicity levels }\left(\mathrm{IC}_{25}\right) \\
\text { at medium and high cytotoxicity levels }\left(\mathrm{IC}_{50,75,90}\right)\end{array}$ & [189] \\
\hline $\begin{array}{l}\text { ENA+ENA }_{1} \\
\text { Human epithelial colorectal } \\
\text { adenocarcinomia cells: Caco-2 }\end{array}$ & $\begin{array}{l}\text { ENA: } 0.365-5 \\
\text { ENA }_{1}: 0.625-5\end{array}$ & $24 \mathrm{~h}$ & $\begin{array}{l}\text { Antagonistic } \\
\text { Additive }\end{array}$ & $\begin{array}{l}\text { at the lowest fraction affected }\left(\mathrm{IC}_{5}\right) \\
\text { at other fractions affected }\left(\mathrm{IC}_{25}, 50,75,90\right)\end{array}$ & [196] \\
\hline $\begin{array}{l}\text { ENA+ENB } \\
\text { Chinese hamster ovary cells: } \\
\text { CHO-K1 }\end{array}$ & $\begin{array}{l}\text { ENA: } 0.365-5 \\
\text { ENB: } 0.625-5\end{array}$ & $24 \mathrm{~h}$ & $\begin{array}{l}\text { Synergistic } \\
\text { Additive }\end{array}$ & $\begin{array}{l}\text { at low and medium cytotoxicity levels }\left(\mathrm{IC}_{25,50}\right) \\
\text { at high cytotoxicity levels }\left(\mathrm{IC}_{75,90}\right)\end{array}$ & [189] \\
\hline $\begin{array}{l}\text { ENA+ENB } \\
\text { Human epithelial colorectal } \\
\text { adenocarcinomia cells: Caco-2 }\end{array}$ & $\begin{array}{l}\text { ENA: } 0.365-5 \\
\text { ENB: } 0.625-5\end{array}$ & $24 \mathrm{~h}$ & $\begin{array}{l}\text { Antagonistic } \\
\text { Additive }\end{array}$ & $\begin{array}{l}\text { at the lowest fraction affected }\left(\mathrm{IC}_{5}\right) \\
\text { at other fractions affected }\left(\mathrm{IC}_{25}, 50,75,90\right)\end{array}$ & [196] \\
\hline $\begin{array}{l}\text { ENA+ENB }{ }_{1} \\
\text { Chinese hamster ovary cells: } \\
\text { CHO-K1 }\end{array}$ & $\begin{array}{l}\text { ENA: } 0.365-5 \\
\text { ENB }_{1}: 0.625-5\end{array}$ & $24 \mathrm{~h}$ & Additive & at all inhibitory concentration levels $\left(\mathrm{IC}_{25,50,75,90}\right)$ & [189] \\
\hline $\begin{array}{l}\text { ENA+ENB }_{1} \\
\text { Human epithelial colorectal } \\
\text { adenocarcinomia cells: Caco-2 }\end{array}$ & $\begin{array}{l}\text { ENA: } 0.365-5 \\
\text { ENB }_{1}: 0.625-5\end{array}$ & $24 \mathrm{~h}$ & $\begin{array}{l}\text { Antagonistic } \\
\text { Additive }\end{array}$ & $\begin{array}{l}\text { at the lowest fraction affected }\left(\mathrm{IC}_{5}\right) \\
\text { at other fractions affected }\left(\mathrm{IC}_{25}, 50,75,90\right)\end{array}$ & [196] \\
\hline $\begin{array}{l}\text { ENA }_{1}+\text { ENB } \\
\text { Chinese hamster ovary cells: } \\
\text { CHO-K1 }\end{array}$ & $\begin{array}{l}\text { EN A }_{1}: 0.365-5 \\
\text { ENB: } 0.625-5\end{array}$ & $24 \mathrm{~h}$ & Additive & at all inhibitory concentration levels $\left(\mathrm{IC}_{25,50,75,90)}\right.$ & [189] \\
\hline $\begin{array}{l}\text { ENA }_{1}+\text { ENB } \\
\text { Human epithelial colorectal } \\
\text { adenocarcinoma cells: Caco-2 }\end{array}$ & $\begin{array}{c}\text { EN A } A_{1}: 0.365-5 \\
\text { ENB: } 0.625-5\end{array}$ & $24 \mathrm{~h}$ & $\begin{array}{l}\text { Antagonistic } \\
\text { Additive } \\
\text { Synergistic }\end{array}$ & $\begin{array}{l}\text { at the lowest fraction affected }\left(\mathrm{IC}_{5}\right) \\
\text { at medium fractions affected }\left(\mathrm{IC}_{25}, 50,75\right) \\
\text { at the highest fraction affected }\left(\mathrm{IC}_{90}\right)\end{array}$ & [196] \\
\hline
\end{tabular}


Table 2. Cont.

\begin{tabular}{|c|c|c|c|c|c|}
\hline Mycotoxin Couples/Cells & Doses $(\mu \mathrm{M})$ & Exposure & & Toxicological Effect & References \\
\hline $\begin{array}{l}\text { ENA }_{1}+\mathbf{E N B}_{1} \\
\text { Chinese hamster ovary cells: } \\
\text { CHO-K1 }\end{array}$ & $\begin{array}{l}\text { EN A }_{1}: 0.365-5 \\
\text { ENB }_{1}: 0.625-5\end{array}$ & $24 \mathrm{~h}$ & $\begin{array}{l}\text { Synergistic } \\
\text { Additive }\end{array}$ & $\begin{array}{l}\text { at low, medium and high cytotoxicity levels }\left(\mathrm{IC}_{25,50,75}\right) \\
\left.\text { at very high cytotoxicity levels (IC }{ }_{90}\right)\end{array}$ & [189] \\
\hline $\begin{array}{l}\mathbf{E N A}_{\mathbf{1}}+\mathbf{E N B}_{1} \\
\text { Human epithelial colorectal } \\
\text { adenocarcinoma cells: Caco-2 }\end{array}$ & $\begin{array}{l}\text { EN A }_{1}: 0.365-5 \\
\text { ENB }_{1}: 0.625-5\end{array}$ & $24 \mathrm{~h}$ & $\begin{array}{l}\text { Additive } \\
\text { Synergistic }\end{array}$ & $\begin{array}{l}\text { at the lowest fraction affected }\left(\mathrm{IC}_{5}\right) \\
\text { at medium fractions affected }\left(\mathrm{IC}_{25}, 50\right) \\
\text { at the two highest fractions affected }\left(\mathrm{IC}_{75}, 90\right)\end{array}$ & [196] \\
\hline $\begin{array}{l}\text { ENB+ENB } 1 \\
\text { Chinese hamster ovary cells: } \\
\text { CHO-K1 }\end{array}$ & $\begin{array}{l}\text { ENB: } 0.365-5 \\
\text { ENB }_{1}: 0.625-5\end{array}$ & $24 \mathrm{~h}$ & Additive & at all inhibitory concentration levels $\left(\mathrm{IC}_{25,50,75,90)}\right.$ & [189] \\
\hline $\begin{array}{l}\text { ENB+ENB }_{1} \\
\text { Human epithelial colorectal } \\
\text { adenocarcinoma cells: Caco-2 }\end{array}$ & $\begin{array}{l}\text { ENB: } 0.365-5 \\
\text { ENB }_{1}: 0.625-5\end{array}$ & $24 \mathrm{~h}$ & $\begin{array}{l}\text { Antagonistic } \\
\text { Additive }\end{array}$ & $\begin{array}{l}\text { at the two lowest fractions affected }\left(\mathrm{IC}_{5,25}\right) \\
\text { at other fractions affected }\left(\mathrm{IC}_{50}, 75,90\right)\end{array}$ & [196] \\
\hline $\begin{array}{l}\text { ENA+ENA } 1+\text { ENB } \\
\text { Chinese hamster ovary cells: } \\
\text { CHO-K1 }\end{array}$ & $\begin{array}{l}\text { ENA: } 0.3125-2.5 \\
\text { ENA }_{1}: 0.3125-2.5 \\
\text { ENB: }_{0} 0.3125-2.5\end{array}$ & $24 \mathrm{~h}$ & $\begin{array}{l}\text { Synergistic } \\
\text { Additive }\end{array}$ & $\begin{array}{l}\text { at low and medium cytotoxicity levels }\left(\mathrm{IC}_{25,50}\right) \\
\text { at high cytotoxicity levels }\left(\mathrm{IC}_{75,90}\right)\end{array}$ & [189] \\
\hline $\begin{array}{l}\text { ENA+ENA }+ \text { ENB } \\
\text { Human epithelial colorectal } \\
\text { adenocarcinoma cells: Caco-2 }\end{array}$ & $\begin{array}{l}\text { ENA: } 1.25-5 \\
\text { ENA }_{1}: 1.25-5 \\
\text { ENB: } 1.25-5\end{array}$ & $24 \mathrm{~h}$ & $\begin{array}{l}\text { Antagonistic } \\
\text { Additive } \\
\text { Synergistic }\end{array}$ & $\begin{array}{l}\text { at the lowest fraction affected }\left(\mathrm{IC}_{5}\right) \\
\text { at medium fractions affected }\left(\mathrm{IC}_{25}, 50\right) \\
\text { at the two highest fractions affected }\left(\mathrm{IC}_{75}, 90\right)\end{array}$ & [196] \\
\hline $\begin{array}{l}\text { ENA+ENA }_{1}+\mathrm{ENB}_{1} \\
\text { Chinese hamster ovary cells: } \\
\text { CHO-K1 }\end{array}$ & $\begin{array}{l}\text { ENA: } 0.3125-2.5 \\
\text { ENA }_{1}: 0.3125-2.5 \\
\text { ENB }_{1}: 0.3125-2.5\end{array}$ & $24 \mathrm{~h}$ & $\begin{array}{l}\text { Synergistic } \\
\text { Additive } \\
\text { Antagonistic }\end{array}$ & $\begin{array}{l}\text { at low and medium cytotoxicity levels }\left(\mathrm{IC}_{25,50}\right) \\
\text { at high cytotoxicity level }\left(\mathrm{IC}_{75}\right) \\
\text { at very high cytotoxicity level }\left(\mathrm{IC}_{90}\right)\end{array}$ & [189] \\
\hline $\begin{array}{l}\text { ENA+ENA }_{1}+\text { ENB }_{1} \\
\text { Human epithelial colorectal } \\
\text { adenocarcinoma cells: Caco-2 }\end{array}$ & $\begin{array}{l}\text { ENA: } 1.25-5 \\
\text { ENA }_{1}: 1.25-5 \\
\text { ENB }_{1}: 1.25-5\end{array}$ & $24 \mathrm{~h}$ & $\begin{array}{l}\text { Antagonistic } \\
\text { Additive }\end{array}$ & $\begin{array}{l}\text { at the lowest fraction affected }\left(\mathrm{IC}_{5}\right) \\
\text { at other fractions affected }\left(\mathrm{IC}_{25}, 50,75,90\right)\end{array}$ & [196] \\
\hline $\begin{array}{l}\text { ENA+ENB+ENB } 1 \\
\text { Chinese hamster ovary cells: } \\
\text { CHO-K1 }\end{array}$ & $\begin{array}{l}\text { ENA: } 0.3125-2.5 \\
\text { ENB: } 0.3125-2.5 \\
\text { ENB }_{1}: 0.3125-2.5 \\
\end{array}$ & $24 \mathrm{~h}$ & $\begin{array}{l}\text { Synergistic } \\
\text { Additive }\end{array}$ & $\begin{array}{l}\text { at low and medium cytotoxicity levels }\left(\mathrm{IC}_{25,50}\right) \\
\text { at high cytotoxicity levels }\left(\mathrm{IC}_{75,90}\right)\end{array}$ & [189] \\
\hline $\begin{array}{l}\text { ENA+ENB+ENB } 1 \\
\text { Human epithelial colorectal } \\
\text { adenocarcinoma cells: Caco-2 }\end{array}$ & $\begin{array}{l}\text { ENA: } 1.25-5 \\
\text { ENB: } 1.25-5 \\
\text { ENB }_{1}: 1.25-5\end{array}$ & $24 \mathrm{~h}$ & $\begin{array}{l}\text { Antagonistic } \\
\text { Additive }\end{array}$ & $\begin{array}{l}\text { at the lowest fraction affected }\left(\mathrm{IC}_{5}\right) \\
\text { at other fractions affected }\left(\mathrm{IC}_{25}, 50,75,90\right)\end{array}$ & [196] \\
\hline $\begin{array}{l}\text { ENA }_{1}+\mathrm{ENB}_{+}+\mathrm{ENB}_{1} \\
\text { Chinese hamster ovary cells: } \\
\text { CHO-K1 }\end{array}$ & $\begin{array}{l}\text { ENA }_{1}: 0.3125-2.5 \\
\text { ENB: } 0.3125-2.5 \\
\text { ENB }_{1}: 0.3125-2.5 \\
\end{array}$ & $24 \mathrm{~h}$ & $\begin{array}{l}\text { Synergistic } \\
\text { Additive } \\
\text { Antagonistic }\end{array}$ & $\begin{array}{l}\text { at low cytotoxicity level }\left(\mathrm{IC}_{25}\right) \\
\text { at medium and high cytotoxicity levels }\left(\mathrm{IC}_{50,75}\right) \\
\text { at very high cytotoxicity level (IC } 90 .\end{array}$ & [189] \\
\hline $\begin{array}{l}\text { EN A }_{1}+\mathbf{E N B}_{1}+\mathrm{ENB}_{1} \\
\text { Human epithelial colorectal } \\
\text { adenocarcinoma cells: Caco-2 }\end{array}$ & $\begin{array}{l}\text { ENA }_{1}: 1.25-5 \\
\text { ENB: }_{1} .25-5 \\
\text { ENB }_{1}: 1.25-5\end{array}$ & $24 \mathrm{~h}$ & $\begin{array}{l}\text { Antagonistic } \\
\text { Additive }\end{array}$ & $\begin{array}{l}\text { at the lowest fraction affected }\left(\mathrm{IC}_{5}\right) \\
\text { at other fractions affected }\left(\mathrm{IC}_{25}, 50,75,90\right)\end{array}$ & [196] \\
\hline $\begin{array}{l}\text { ENA+ENA } 1+\text { ENB+ENB } \\
\text { Human epithelial colorectal } \\
\text { adenocarcinoma cells: Caco-2 }\end{array}$ & $\begin{array}{c}\text { ENA: } 1.25-5 \\
\text { ENA }_{1}: 1.25-5 \\
\text { ENB: } 1.25-5 \\
\text { ENB }_{1}: 1.25-5\end{array}$ & $24 \mathrm{~h}$ & $\begin{array}{l}\text { Antagonistic } \\
\text { Additive }\end{array}$ & $\begin{array}{l}\text { at the lowest fraction affected }\left(\mathrm{IC}_{5}\right) \\
\text { at other fractions affected }\left(\mathrm{IC}_{25}, 50,75,90\right)\end{array}$ & [196] \\
\hline
\end{tabular}

Abbreviations: deoxynivalenol (DON); 3-acetyldeoxynivalenol (3-ADON); 15-acetyldeoxynivalenol (15-ADON); nivalenol (NIV); fusarenone-X (FUS-X); T-2 toxin (T-2); beauvericin (BEA); fumonisin B1 (FB1); zearalenone (ZEA); $\alpha$-zearalenol ( $\alpha$-ZOL); $\beta$-zearalenol ( $\beta$-ZOL); enniatins A, A1, B, B1 (ENA, ENA1,ENB, ENB1) 


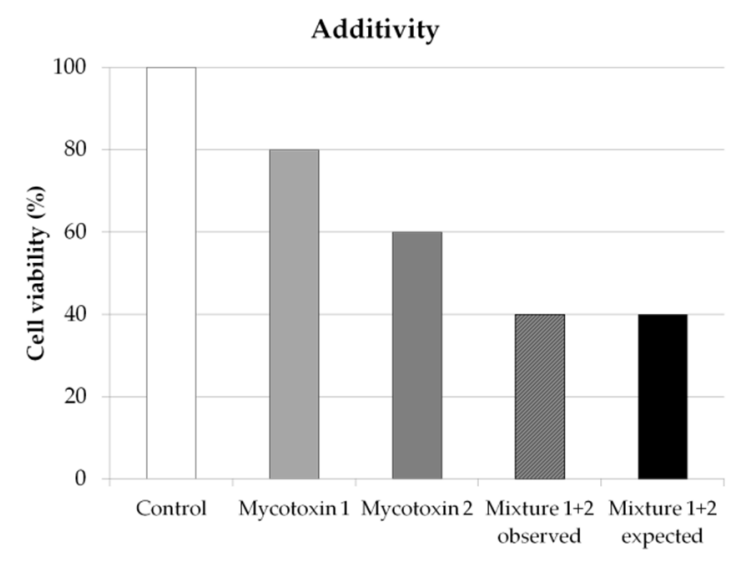

(a)

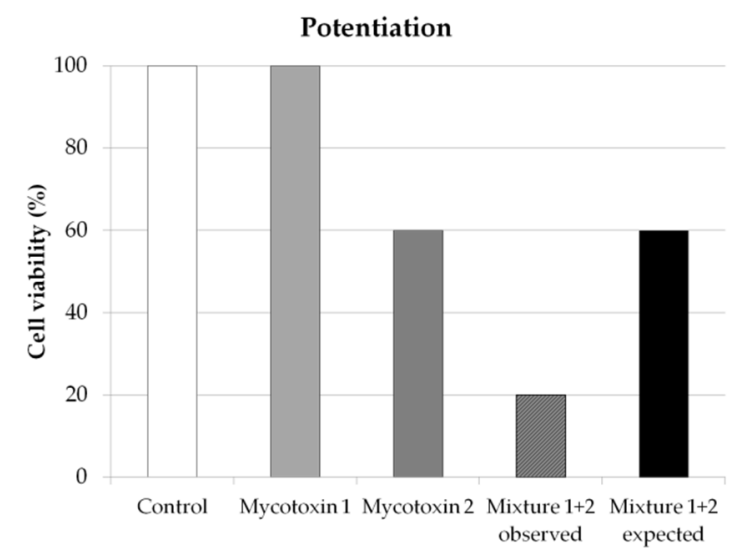

(c)

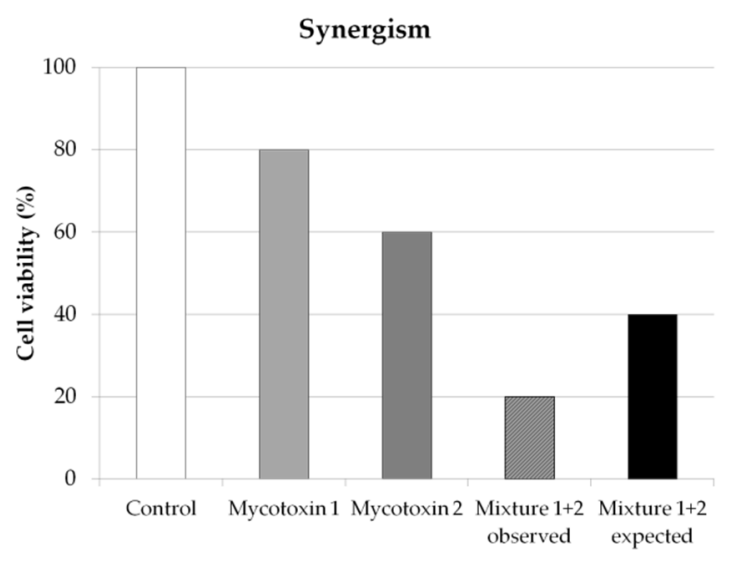

(b)

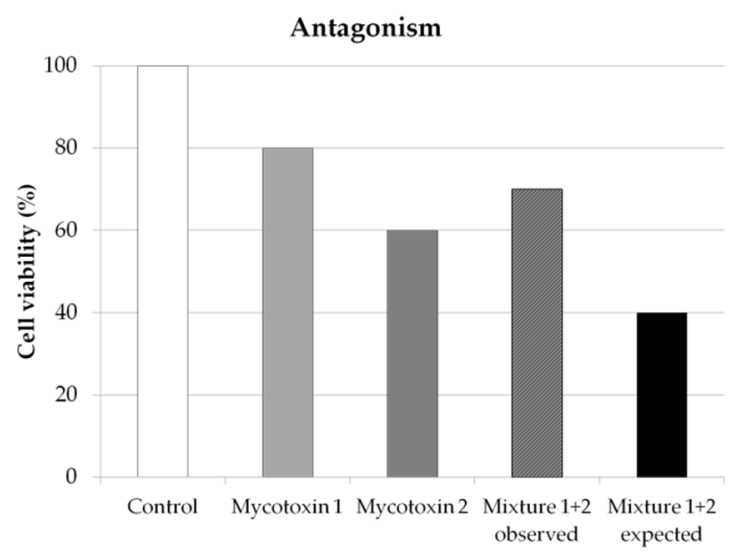

(d)

Figure 5. Characterization of the interaction between mycotoxins.

A deeper view of the different interactions between mycotoxins can be found in the review by Grenier and Oswald [6], in which three types of synergism are presented and two kinds of antagonistic effects are itemized.

\subsection{Main Experimental Designs for Studying Mycotoxin Interactions}

Several experimental designs can be used for studying mycotoxin interactions. Klarić et al. [152] briefly described the main mathematical designs used for this purpose: central composite design (CCD), full factorial design, ray design, isobolographic analyses/combination index, and the arithmetic definition of additivity. Some authors used other approaches such as the interaction index V [159] and the coefficient of drug interaction (CDI) [210] to characterize the type of interaction. The aim of all these experimental designs is to predict combined mycotoxin effects based on the comparison between the observed and expected effects of a mycotoxin mixture. The most used models are described hereafter.

The main approach is the one applied by Weber et al. [212] and used in more than $30 \%$ of the 58 studies. This method is based on the comparison of theoretical expected values calculated on the basis of mono-exposure experiment results with the observed values obtained from co-exposure experiment. In the case of binary mycotoxin combination exposure, the expected cell viability value is calculated as follows:

Cell viability expected value for Mycotoxin1 + Mycotoxin2 (\%)

$=$ mean cell viability for Mycotoxin $1(\%)+$ mean cell viability for Mycotoxin2 $(\%)$

- mean control condition (100\%) 
The expected standard error of mean (S.E.M.) is calculated as follows:

$$
\begin{gathered}
\text { S.E.M. expected for Mycotoxin1 }+ \text { Mycotoxin2 } \\
=\left[(\text { S.E.M. for Mycotoxin1 })+(\text { S.E.M. for Mycotoxin2) }]^{1 / 2}\right.
\end{gathered}
$$

Combined cytotoxic effects are determined by comparison between each expected value and the corresponding measured mean value obtained from co-exposure experiments, often using an unpaired $t$-test. No statistical difference between expected and measured cell viability values is interpreted as an additive effect on cell viability reduction, whereas a synergistic or antagonistic effects are determined if the measured cell viability values are respectively significantly below or above the expected values.

The second most used method, applied in $22 \%$ of the analyzed articles, is the combination index-isobologram analysis also known as the Chou-Talalay method [213,214], derived from the Median-effect principle and originally used for analyzing drug combination effects. In isobolographic analyses, the isoeffective points can be interpolated from the results (of cell viability tests for example) and used to plot the isobologram, represented by a line joining equally effective doses (Figure 6). In this type of graph, the additive effect follows the diagonal line between the effective concentrations of each single mycotoxin. If the measured combined effect of two mycotoxins is above or below the diagonal line, it indicates an antagonist or a synergistic effect of the combination respectively. Chou introduced the term "combination index" (CI) to quantify the degree of mycotoxin interaction between two or more mycotoxins [213]. The CI method is often used to analyze the mycotoxin interaction, and the $\mathrm{CI}$ values are calculated as follows:

$$
(\mathrm{CI})_{x}^{n}=\sum_{j=1}^{n} \frac{(D)_{j}}{\left(D_{x}\right)_{j}}
$$

where $(\mathrm{CI})_{x}^{n}$ is the $\mathrm{CI}$ for $n$ mycotoxins at $x \%$ cell viability inhibition, $(D)_{j}$ is the doses of $n$ toxins that exerts $x \%$ inhibition in combination, $\left(D_{x}\right)_{j}$ is the doses of each of $n$ mycotoxins alone that exerts $x \%$ inhibition.

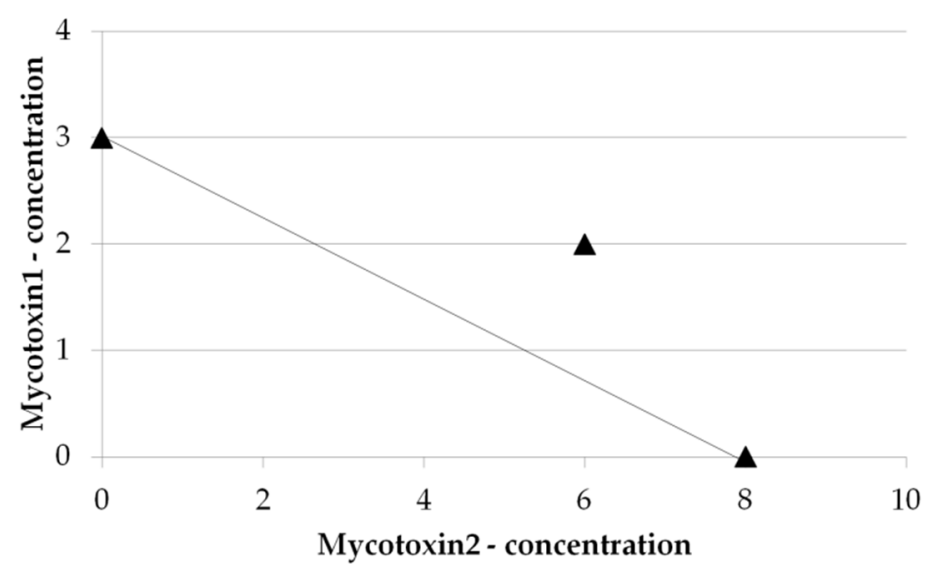

Figure 6. Isobologram illustrating the antagonist effect of two mycotoxins for reaching $x \%$ of cell viability inhibition.

A CI near 1 indicates an additive effect, $\mathrm{CI}<1$ indicates synergism, and $\mathrm{CI}>1$ indicates antagonism of the combined mycotoxins. The CI-isobologram method allows not only for determination of the type of interaction but also of its magnitude. This is presented in more detail by Ruiz et al. [197] and others.

Only four authors used a CCD including a full or fractional factorial design for mixtures $[173,188,202,209]$. Briefly, the CCD is used in order to minimize the number of possible toxin combinations from all possible combinations of every concentration ( $m$ concentrations) of each 
toxin ( $k$ toxins) $=m k$, to $n=2 k / 2$ cube points $+2 k$ star points +1 center point. Then, a full or fractional factorial design is applied to detect interactions at various mixture ratios [173]. Nevertheless, when the number of mycotoxins increases and the number of design points needed to study the toxin mixtures becomes too high, another alternative is the ray design providing constant mixture ratios and thus reducing the amount of experimental efforts. Only one author group out of the 58 analyzed articles used this design [203].

The sample number is not a limiting factor regardless of the considered model. However, the simplest and the most intuitive mathematical design seems to be the arithmetic definition of additivity and applied by Weber et al. [212] because it is based on a simple additivity of the individual mycotoxin toxicological effect values. Nevertheless, this definition of the combined effects, namely simply defined by the sum of single effects, is questionable, and the example of the combined effect study of the sum of several doses of the same mycotoxin, which cannot be synergistic or antagonistic, highlights this point.

It could be interesting to use different statistical models to analyze a specific mycotoxin mixture under identical exposure conditions to verify the similarity of the results and conclusions, and thus, to determine if it is necessary to standardize the method.

\subsection{In Vitro Interactions Between Fusariotoxins}

The global results from in vitro cell viability studies concerning fusariotoxin mixtures (subdivided in as follows: TCT mixtures; TCT + fusariotoxins and other fusariotoxins mixtures) are presented in Table 2. According to the analyzed studies, trichothecenes as well as other fusariotoxins (ZEA, FUM and emerging mycotoxins), individually and in combination, inhibit cell viability in vitro.

Alassane-Kpembi et al. [154,155] showed that combination of DON and its acetylated derivatives 3-DON and/or 15-ADON mainly resulted in synergistic cytotoxicity on porcine IPEC-1 and human Caco-2 cells, and particularly at low inhibitory concentration levels (Inhibitory Concentrations from $10 \%$ to $\left.30 \%=\mathrm{IC}_{10}-\mathrm{IC}_{30}\right)$ on Caco-2. Additive effects were observed at higher doses $\left(\mathrm{IC}_{50}\right)$. Concerning one of the most studied mixtures, DON+NIV, multiple effects have been observed. The same authors showed synergistic effects on Caco-2 and IPEC-1 (between 0.2 and $15 \mu \mathrm{M}$ ) [154,155], while Wan et al. observed antagonistic effect at $0.5 \mu \mathrm{M}$ and synergism at $2 \mu \mathrm{M}$ on porcine IPEC-J2 [209], whereas Marzocco et al. described additivity at medium cytotoxicity level $\left(\mathrm{IC}_{50}\right.$, or $\left.15 \mu \mathrm{M}\right)$ on murine J774A.1 [194]. DON+FX resulted in synergistic cytotoxicity on Caco-2 and antagonistic effect on IPEC-1, whereas NIV+FX resulted in synergistic effect at low cytotoxicity levels $\left(\mathrm{IC}_{10}-\mathrm{IC}_{20}\right)$ and additivity at higher inhibitory concentration levels $\left(\mathrm{IC}_{30}-\mathrm{IC}_{50}\right)$ on Caco-2 and only additivity on IPEC-1 ( $\left.\mathrm{IC}_{10}-\mathrm{IC}_{80}\right)$ [154,155]. For DON+T2, antagonism was observed with acute exposure (24 to $72 \mathrm{~h}$ ) on Chinese hamster CHO-K1 and monkey Vero cells [197,198], and additivity was reported with human progenitors CFU-GM with 14 days of exposure [166]. Therefore, even if a global observation of synergistic toxicity was often observed at low cytotoxicity doses $\left(\mathrm{IC}_{10}-\mathrm{IC}_{30}\right)$, trichothecene mixtures resulted in various cytotoxicity effects which seem to depend on the studied mycotoxin combination, the used cell model, the time of exposure and the tested concentration.

Several authors were interested in mixtures of TCT and other fusariotoxins, such as FB1, ZEA, and the emerging mycotoxin BEA. Again, the conclusions of the different authors and studies were species- and organ-dependent: Ruiz et al. observed antagonistic effects on hamster $\mathrm{CHO}-\mathrm{K} 1$ and monkey Vero cells with DON+BEA co-exposure [197,198], whereas Ficheux et al. showed synergism on human CFU-GM [166]. Ruiz et al. also studied T2+BEA and showed opposite cytotoxic effect on $\mathrm{CHO}-\mathrm{K} 1$ and Vero cells (synergism and antagonism respectively) despite the similar mycotoxin doses, the same time of exposure ( 24 to $72 \mathrm{~h}$ ) and the same used assessment to measure cell viability (neutral red assay) [197,198]. These opposite observations highlight the complexity of the mycotoxin interactions, with the influence of the used cell models (studied species and targeted organs).

Regarding the ternary mixture DON+T2+BEA studied by Ruiz et al., the effects were the same as those observed for T2+BEA on CHO-K1 and Vero cells [197,198]. Ficheux et al. [166] as well as Wan et al. [209] observed antagonistic effects with DON+FB1 on CFU-GM and IPEC-J2 at low 
concentrations, respectively (less than $0.5 \mu \mathrm{M}$ DON and $20 \mu \mathrm{M}$ FB1), whereas Kouadio et al. showed additivity on Caco-2 at similar doses [187]. Wan et al. also observed the same effect on IPEC-J2 with $\mathrm{NIV}+\mathrm{FB} 1$ and $\mathrm{DON}+\mathrm{NIV}+\mathrm{FB} 1$, that DON+FB1 (namely antagonism at the lowest dose $(0.5 \mu \mathrm{M} \mathrm{DON}$ and NIV, and $20 \mu \mathrm{M}$ FB1) and synergism at the highest dose (2 $\mu \mathrm{M}$ DON and NIV, and $40 \mu \mathrm{M}$ FB1) [209]. Concerning DON+ZEA, another mixture of interest, Kouadio et al. [187] as well as Ficheux et al. [166] showed additive cytotoxicity on Caco-2 and CFU-GM respectively, whereas Wan et al. [209] and Bensassi et al. [156] observed antagonism on IPEC-J2 and human HCT116 cells respectively, like for NIV+ZEA and DON+NIV+ZEA [209]. Ficheux et al. [166] and Bouaziz et al. [158] showed the additivity of T2+ZEA on CFU-GM and Vero cells. Wan et al. also studied DON+ZEA+FB1, NIV+ZEA+FB1 and $\mathrm{DON}+\mathrm{NIV}+\mathrm{ZEA}+\mathrm{FB1}$ mixtures, and observed the same effects, namely antagonism at the lowest dose

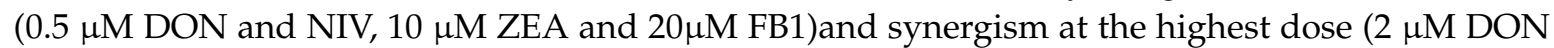
and NIV, and $40 \mu \mathrm{M}$ ZEA and FB1), as all the other mixtures they studied on IPEC-J2 [209], whereas Kouadio et al. showed additivity for DON+ZEA+FB1 on Caco-2 [187].

Concerning the mixtures involving ZEA, FB1 and emerging mycotoxins such as BEA and ENs, a major part presented antagonistic or additive cytotoxic effects. In particular, ZEA and its derivatives $\alpha$ - and $\beta$-zearalenol ( $\alpha$-ZOL and $\beta$-ZOL) in binary and ternary mixtures were studied by Wang et al. [208] and Tatay et al. [204]. Wang et al. showed mainly an antagonistic effect of ZEA+ $\alpha-Z O L$ on HepG2 [208], whereas Tatay et al. mostly observed additivity between ZEA and its derivatives on CHO-K1 [204]. Regarding ZEA+FB1, Kouadio et al. [187] and Wan et al. [209] observed antagonistic effects on Caco-2 and IPEC-J2. Klarić et al. showed additivity of FB1+BEA at the lowest concentration (about $0.06 \mu \mathrm{M}$ BEA and FB1) and synergism at the highest dose (about $6 \mu \mathrm{M}$ BEA and FB1) on PK15 cells [180]. Concerning emerging mycotoxin mixtures, Ficheux et al. studied BEA+ENB and observed additivity on CFU-GM after 14 days [166]. Finally, several authors [189,196] studied binary, ternary, and quaternary EN mixtures (ENA, ENA1, ENB, and ENB1) and in similar concentrations, with the same cell viability assessment and time of exposure (MTT assay, during $24 \mathrm{~h}$ ). Globally, Lu et al. observed synergistic effects at low cytotoxicity levels $\left(\mathrm{IC}_{25}\right)$ and additivity at medium and high inhibitory concentration levels $\left(\mathrm{IC}_{50}-\mathrm{IC}_{90}\right)$ on $\mathrm{CHO}-\mathrm{K} 1[189,196]$, whereas Prosperini et al. indicated antagonism at low cytotoxicity levels $\left(\mathrm{IC}_{5}-\mathrm{IC}_{25}\right)$ and additivity at medium and high inhibitory concentration levels $\left(\mathrm{IC}_{50}-\mathrm{IC}_{90}\right)$ on Caco-2 cells $[189,196]$, highlighting, once again, the influence, among other, of the type of cell used.

Thus, observed effects are not necessarily dose- and time-dependent. For example, the studies of ENA+ENA1 combined effects by $\mathrm{Lu}$ et al. and Prosperini et al. showed opposite conclusions on CHO-K1 and Caco-2 cells respectively, after $24 \mathrm{~h}$ exposure and at the same ENA and ENA1 concentrations [189,196]. Moreover, for a same cell model, interspecies and intraspecies sensitivity depends on tested mixtures. For example, concerning intestinal epithelial cells, exposure effect to DON+NIV were antagonist at low doses $(0.5-2 \mu \mathrm{M})$ for IPEC-J2 (porcine jejunal epithelial cells) and synergistic for IPEC-1 (mix of porcine jejunal and ileal epithelial cells) and human Caco-2 cells. Another observation is for a model cell culture like Caco- 2 for example, the number of mycotoxins tested in mixtures could not be predictive of a potential additive or synergistic effect. For example, DON+FX as well as DON+NIV and NIV+FX led to synergistic effect but DON+FX+NIV showed antagonistic effect [155].

Currently, the mycotoxin toxicological combined effects are unpredictable based on their individual effects, despite an increasing number of co-exposure studies.

\section{Conclusion}

Mycotoxins are present in a large range of feed and food, all over the world, in different concentrations, mainly depending on mould genetics and physiology, outdoor and indoor environment and climate changes. Even if certain mycotoxins often occur together (e.g., AFs+OTA, AFs+FUM or DON+ZEA), an infinity of mixtures may be found. Therefore, combined toxicity effects are very hard to predict. In addition to being influenced by the type of mycotoxin mixtures and their concentrations, 
combined toxicity effects depend on the experimental model design: type of cells exposed, time of exposure, ratio used for each mycotoxin in the mixture, endpoints and tests used, as well as chosen statistical model aspects. In general, most of the mycotoxin mixtures lead to additive or synergistic effects, highlighting a significant threat to human and animal health. Moreover, most studies have been carried out over less than three days, at concentrations above the legal limits. There is therefore a lack of data about chronic exposure at sub-toxic mycotoxin concentrations, closer to real food and feed consumption habits. Through a large panel of mycotoxin contamination studies in food and feed around the world, this review constitutes a strong basis of work, allowing for each continent to have an overview of the multicontaminations and to focus on these ones. Diverse publications already showed important combined effects but more studies about relevant mycotoxin combinations should be carried out and especially should be taken into account by the current regulations which only consider so-far mono-exposure data. Finally, the observed diversity of the possible methodological approaches useable (cell models, studied parameters, time and dose exposure, mathematical tools) raises the question of the need for method standardization at an international level allowing for easier data comparison.

Acknowledgments: The authors are thankful to Gaëtan Le Floch (Université de Brest, LUBEM, EA 3882) for his help for the statistical analysis of mycotoxin mixtures depending on their geographical location.

Conflicts of Interest: The authors declare no conflict of interest.

\section{Abbreviations}

The following abbreviations are used in this manuscript:

$\begin{array}{ll}3 \text {-ADON } & \text { 3-acetyldeoxynivalenol } \\ \text { 15-ADON } & \text { 15-acetyldeoxynivalenol } \\ \alpha \text {-ZOL } & \alpha \text {-zearalenol } \\ \beta \text {-ZOL } & \beta \text {-zearalenol } \\ \text { AFs } & \text { aflatoxins } \\ \text { BEA } & \text { beauvericine } \\ \text { DAS } & \text { diacetoxyscirpenol } \\ \text { DON } & \text { deoxynivalenol } \\ \text { EC } & \text { European Commission } \\ \text { EFSA } & \text { European Food Safety Authority } \\ \text { ENA, ENA1,ENB, ENB1 } & \text { enniatins A, A1, B, B1 } \\ \text { ENs } & \text { enniatins } \\ \text { FAO } & \text { Food and Agriculture Organization } \\ \text { FDA } & \text { Food and Drug Administration } \\ \text { FB1, FB2, FB3 } & \text { fumonisin B1, B2, B3 } \\ \text { FUM } & \text { fumonisins } \\ \text { FUS-X } & \text { fusarenone-X } \\ \text { IC } & \text { inhibitory concentration } \\ \text { HT-2 } & \text { HT-2 toxin } \\ \text { MON } & \text { moniliformin } \\ \text { NIV } & \text { nivalenol } \\ \text { OTA } & \text { ochratoxin A } \\ \text { TCTs } & \text { trichothecenes } \\ \text { T-2 } & \text { T-2 toxin } \\ \text { ZEA } & \text { zearalenone } \\ \text { WHO } & \text { World Health Organization } \\ & \end{array}$




\section{References}

1. Bryden, W.L. Mycotoxin contamination of the feed supply chain: Implications for animal productivity and feed security. Anim. Feed Sci. Technol. 2012, 173, 134-158. [CrossRef]

2. Marin, S.; Ramos, A.J.; Cano-Sancho, G.; Sanchis, V. Mycotoxins: Occurrence, toxicology, and exposure assessment. Food Chem. Toxicol. 2013, 60, 218-237. [CrossRef] [PubMed]

3. Milani, J.M. Ecological conditions affecting mycotoxin production in cereals: A review. Vet. Med. Czech Repub. 2013, 58, 405-411.

4. Da Rocha, M.E.B.; da Freire, F.C.O.; Maia, F.E.F.; Guedes, M.I.F.; Rondina, D. Mycotoxins and their effects on human and animal health. Food Control 2014, 36, 159-165. [CrossRef]

5. Bullerman, L.B.; Bianchini, A. Stability of mycotoxins during food processing. Int. J. Food Microbiol. 2007, 119, 140-146. [CrossRef] [PubMed]

6. Grenier, B.; Oswald, I. Mycotoxin co-contamination of food and feed: meta-analysis of publications describing toxicological interactions. World Mycotoxin J. 2011, 4, 285-313. [CrossRef]

7. CAST Report. Task Force Report N 139. In Mycotoxins: Risks in plant, animal, and human systems; Richard, J.L., Payne, G.A., Eds.; Council for Agricultural Science and Technology: Ames, IA, USA, 2003.

8. Binder, E.M.; Tan, L.M.; Chin, L.J.; Handl, J.; Richard, J. Worldwide occurrence of mycotoxins in commodities, feeds and feed ingredients. Anim. Feed Sci. Technol. 2007, 137, 265-282. [CrossRef]

9. Clarke, R.; Connolly, L.; Frizzell, C.; Elliott, C.T. Cytotoxic assessment of the regulated, co-existing mycotoxins aflatoxin B1, fumonisin B1 and ochratoxin, in single, binary and tertiary mixtures. Toxicon 2014, 90, 70-81. [CrossRef] [PubMed]

10. Streit, E.; Naehrer, K.; Rodrigues, I.; Schatzmayr, G. Mycotoxin occurrence in feed and feed raw materials worldwide: Long-term analysis with special focus on Europe and Asia. J. Sci. Food Agric. 2013, 93, 2892-2899. [CrossRef] [PubMed]

11. Jestoi, M. Emerging Fusarium-Mycotoxins fusaproliferin, beauvericin, enniatins, and moniliformin-A review. Crit. Rev. Food Sci. Nutr. 2008, 48, 21-49. [CrossRef] [PubMed]

12. Grenier, B.; Applegate, T.J. Modulation of intestinal functions following mycotoxin ingestion: Meta-analysis of published experiments in animals. Toxins 2013, 5, 396-430. [CrossRef] [PubMed]

13. Kadota, T.; Furusawa, H.; Hirano, S.; Tajima, O.; Kamata, Y.; Sugita-Konishi, Y. Comparative study of deoxynivalenol, 3-acetyldeoxynivalenol, and 15-acetyldeoxynivalenol on intestinal transport and IL-8 secretion in the human cell line Caco-2. Toxicol. In Vitro 2013, 27, 1888-1895. [CrossRef] [PubMed]

14. EC, (European Commission). Commission regulation (EC) No 1881/2006 of 19 December 2006 (consolidated version 2014-07-01) setting maximum levels for certain contaminants in foodstuffs. Available online: http:/ / eur-lex.europa.eu/LexUriServ/LexUriServ.do?uri=OJ:L:2006:364:0005:0024:EN:PDF (accessed on 30 November 2015).

15. Van Egmond, H.P.; Jonker, M.A. Worldwide regulations for mycotoxins in food and feed in 2003; Food and Agriculture Organization of the United Nations, 2004.

16. Barug, D., van Egmond, H.P., López-García, R., van Osenbruggen, W.A., Visconti, A., Eds.; Mycotoxins worldwide: Current issues in Africa. In Meeting the mycotoxin menace, Proceedings of the 2nd World Mycotoxin Forum held in Nordwijk, Nordwijk, the Netherlands, 17-18 February 2003; pp. 81-88.

17. Berthiller, F.; Crews, C.; Dall'Asta, C.; Saeger, S.D.; Haesaert, G.; Karlovsky, P.; Oswald, I.P.; Seefelder, W.; Speijers, G.; Stroka, J. Masked mycotoxins: A review. Mol. Nutr. Food Res. 2013, 57, 165-186. [CrossRef] [PubMed]

18. Cirlini, M.; Dall'Asta, C.; Galaverna, G. Hyphenated chromatographic techniques for structural characterization and determination of masked mycotoxins. J. Chromatogr. A 2012, 1255, 145-152. [CrossRef] [PubMed]

19. Rodrigues, I.; Naehrer, K. A three-year survey on the worldwide occurrence of mycotoxins in feedstuffs and feed. Toxins 2012, 4, 663-675. [CrossRef] [PubMed]

20. Gallo, A.; Giuberti, G.; Frisvad, J.C.; Bertuzzi, T.; Nielsen, K.F. Review on mycotoxin issues in ruminants: Occurrence in forages, effects of mycotoxin ingestion on health status and animal performance and ractical strategies to counteract their negative effects. Toxins 2015, 7, 3057-3111. [CrossRef] [PubMed]

21. Speijers, G.J.A.; Speijers, M.H.M. Combined toxic effects of mycotoxins. Toxicol. Lett. 2004, 153, 91-98. [CrossRef] [PubMed] 
22. FDA, (U.S. Food and Drug Administration). Guidance for industry: Action levels for poisonous or deleterious substances in human food and animal feed-Aflatoxin. Available online: http://www.fda.gov/ Food/GuidanceRegulation/GuidanceDocumentsRegulatoryInformation/ChemicalContaminantsMetals NaturalToxinsPesticides/ucm077969.htm\#afla (accessed on 3 December 2015).

23. EC, (European Commission). Directive 2002/32/EC of the European Parliament and of the Council of 7 May 2002 (consolidated version 2013-12-27) on undesirable substances in animal feed. Available online: http:/ / eur-lex.europa.eu/legal-content/EN/TXT/?uri=CELEX:02002L0032-20131227 (accessed on 30 November 2015).

24. Bosco, F.; Molle, C. Mycotoxins in Food. In Food Industrial Processes - Methods and Equipment; Valdez, B., Ed.; InTech: Torino, Italy, 2012.

25. Creppy, E.E. Update of survey, regulation and toxic effects of mycotoxins in Europe. Toxicol. Lett. 2002, 127, 19-28. [CrossRef]

26. Ficheux, A.S.; Sibiril, Y.; le Garrec, R.; Parent-Massin, D. In vitro myelotoxicity assessment of the emerging mycotoxins Beauvericin, Enniatin b and Moniliformin on human hematopoietic progenitors. Toxicon 2012, 59, 182-191. [CrossRef] [PubMed]

27. Filazi, A.; Sireli, U.T. Occurrence of aflatoxins in food. In Aflatoxins-Recent Advances and Future Prospects; Razzaghi-Abyaneh, M., Ed.; InTech: Ankara, Turkey, 2013.

28. Glenn, A.E. Mycotoxigenic Fusarium species in animal feed. Anim. Feed Sci. Technol. 2007, 137, $213-240$. [CrossRef]

29. Logrieco, A.; Moretti, A.; Castella, G.; Kostecki, M.; Golinski, P.; Ritieni, A.; Chelkowski, J. Beauvericin production by Fusarium species. Appl. Environ. Microbiol. 1998, 64, 3084-3088. [PubMed]

30. Oliveira, P.M.; Zannini, E.; Arendt, E.K. Cereal fungal infection, mycotoxins, and lactic acid bacteria mediated bioprotection: From crop farming to cereal products. Food Microbiol. 2014, 37, 78-95. [CrossRef] [PubMed]

31. Pitt, J.I. Toxigenic fungi and mycotoxins. Br. Med. Bull. 2000, 56, 184-192. [CrossRef] [PubMed]

32. Yazar, S.; Omurtag, G.Z. Fumonisins, trichothecenes and zearalenone in cereals. Int. J. Mol. Sci. 2008, 9, 2062-2090. [CrossRef] [PubMed]

33. EC, (European Commission). Commission recommandation of 17 August 2006 on the presence of deoxynivalenol, zearalenone, ochratoxin A, T-2 and HT-2 and fumonisins in products intended for animal feeding. Available online: http://eur-lex.europa.eu/legal-content/EN/TXT/PDF/? uri=CELEX:32006H0576\&from=EN (accessed on 30 November 2015).

34. FDA, (U.S. Food and Drug Administration). Guidance for industry: Fumonisin levels in human foods and animal feeds; final guidance (June 6, 2000; revised November 9, 2001). Available online: http:/ / www.fda.gov/Food/GuidanceRegulation/GuidanceDocumentsRegulatoryInformation/Chemical ContaminantsMetalsNaturalToxinsPesticides/ucm109231.htm (accessed on 3 December 2015).

35. FDA, (U.S. Food and Drug Administration). Guidance for industry and FDA: Advisory levels for deoxynivalenol (DON) in finished wheat products for human consumption and grains and grain by-products used for animal feed (June 29, 2010; Revised July 7, 2010). Available online: http://www.fda.gov/downloads/Food/GuidanceRegulation/UCM217558.pdf (accessed on 3 December 2015).

36. FDA, (U.S. Food and Drug Administration). Compliance Policy Guides - CPG Sec.510.150 Apple juice, apple juice concentrates, and apple juice products - adulteration with patulin (October 22, 2001; revised November 29, 2005). Available online: http://www.fda.gov/iceci/ compliancemanuals/compliancepolicyguidancemanual/ucm074427.htm (accessed on 3 December 2015).

37. Abbas, H.K.; Mirocha, C.J.; Meronuck, R.A.; Pokorny, J.D.; Gould, S.L.; Kommedahl, T. Mycotoxins and Fusarium spp. associated with infected ears of corn in Minnesota. Appl. Environ. Microbiol. 1988, 54, 1930-1933. [PubMed]

38. Abramson, D.; Mills, J.T.; Marquardt, R.R.; Frohlich, A.A. Mycotoxins in fungal contaminated samples of animal feed from western Canada, 1982-1994. Can. J. Vet. Res. 1997, 61, 49-52. [PubMed]

39. Abramson, D.; Clear, R.M.; Nowicki, T.W. Fusarium species and trichothecene mycotoxins in suspect samples of 1985 manitoba wheat. Can. J. Plant Sci. 1987, 67, 611-619. [CrossRef]

40. Ali, N.; Sardjono; Yamashita, A.; Yoshizawa, T. Natural co-occurrence of aflatoxins and Fusarium mycotoxins (fumonisins, deoxynivalenol, nivalenol and zearalenone) in corn from Indonesia. Food Addit. Contam. 1998, 15, 377-384. [CrossRef] [PubMed] 
41. Almeida, I.; Martins, H.M.; Santos, S.; Costa, J.M.; Bernardo, F. Co-occurrence of mycotoxins in swine feed produced in Portugal. Mycotoxin Res. 2011, 27, 177-181. [CrossRef] [PubMed]

42. Alvito, P.C.; Sizoo, E.A.; Almeida, C.M.M.; van Egmond, H.P. Occurrence of aflatoxins and ochratoxin A in baby foods in Portugal. Food Anal. Methods 2010, 3, 22-30. [CrossRef]

43. Bankole, S.A.; Mabekoje, O.O. Occurrence of aflatoxins and fumonisins in preharvest maize from south-western Nigeria. Food Addit. Contam. 2004, 21, 251-255. [CrossRef] [PubMed]

44. Baydar, T.; Engin, A.B.; Girgin, G.; Aydin, S.; Sahin, G. Aflatoxin and ochratoxin in various types of commonly consumed retail ground samples in Ankara, Turkey. Ann. Agric. Environ. Med. AAEM 2005, 12, 193-197. [PubMed]

45. Bircan, C. Incidence of ochratoxin A in dried fruits and co-occurrence with aflatoxins in dried figs. Food Chem. Toxicol. 2009, 47, 1996-2001. [CrossRef] [PubMed]

46. Błajet-Kosicka, A.; Twarużek, M.; Kosicki, R.; Sibiorowska, E.; Grajewski, J. Co-occurrence and evaluation of mycotoxins in organic and conventional rye grain and products. Food Control 2014, 38, 61-66. [CrossRef]

47. Camargos, S.M.; Machinski, M.; Soares, R. Co-occurrence of fumonisins and aflatoxins in freshly harvested Brazilian maize. Trop. Sci. 2001, 41, 182-184.

48. Cano-Sancho, G.; Ramos, A.J.; Marín, S.; Sanchis, V. Presence and co-occurrence of aflatoxins, deoxynivalenol, fumonisins and zearalenone in gluten-free and ethnic foods. Food Control 2012, 26, 282-286. [CrossRef]

49. Cano-Sancho, G.; Valle-Algarra, F.M.; Jiménez, M.; Burdaspal, P.; Legarda, T.M.; Ramos, A.J.; Sanchis, V.; Marín, S. Presence of trichothecenes and co-occurrence in cereal-based food from Catalonia (Spain). Food Control 2011, 22, 490-495. [CrossRef]

50. Castillo, M.-Á.; Montes, R.; Navarro, A.; Segarra, R.; Cuesta, G.; Hernández, E. Occurrence of deoxynivalenol and nivalenol in Spanish corn-based food products. J. Food Compos. Anal. 2008, 21, 423-427. [CrossRef]

51. Cavaliere, C.; D’Ascenzo, G.; Foglia, P.; Pastorini, E.; Samperi, R.; Laganà, A. Determination of type B trichothecenes and macrocyclic lactone mycotoxins in field contaminated maize. Food Chem. 2005, 92, 559-568. [CrossRef]

52. Cerveró, M.C.; Castillo, M.A.; Montes, R.; Hernández, E. Determination of trichothecenes, zearalenone and zearalenols in commercially available corn-based foods in Spain. Rev. Iberoam. Micol. 2007, 24, 52-55. [CrossRef]

53. Chamberlain, W.J.; Bacon, C.W.; Norred, W.P.; Voss, K.A. Levels of fumonisin B1 in corn naturally contaminated with aflatoxins. Food Chem. Toxicol. 1993, 31, 995-998. [CrossRef]

54. Cunha, S.C.; Fernandes, J.O. Development and validation of a method based on a QuEChERS procedure and heart-cutting GC-MS for determination of five mycotoxins in cereal products. J. Sep. Sci. 2010, 33, 600-609. [CrossRef] [PubMed]

55. Doko, M.B.; Canet, C.; Brown, N.; Sydenham, E.W.; Mpuchane, S.; Siame, B.A. Natural co-occurrence of fumonisins and zearalenone in cereals and cereal-based foods from Eastern and Southern Africa. J. Agric. Food Chem. 1996, 44, 3240-3243. [CrossRef]

56. Domijan, A.-M.; Peraica, M.; Cvjetković, B.; Turcin, S.; Jurjević, Z.; Ivić, D. Mould contamination and co-occurrence of mycotoxins in maize grain in Croatia. Acta Pharm. Zagreb Croat. 2005, 55, 349-356.

57. Domijan, A.-M.; Peraica, M.; Jurjević, Ž.; Ivić, D.; Cvjetković, B. Fumonisin B1, fumonisin B2, zearalenone and ochratoxin A contamination of maize in Croatia. Food Addit. Contam. 2005, 22, 677-680. [CrossRef] [PubMed]

58. Driehuis, F.; Spanjer, M.C.; Scholten, J.M.; te Giffel, M.C. Occurrence of mycotoxins in feedstuffs of dairy cows and estimation of total dietary intakes. J. Dairy Sci. 2008, 91, 4261-4271. [CrossRef] [PubMed]

59. Eckard, S.; Wettstein, F.E.; Forrer, H.-R.; Vogelgsang, S. Incidence of Fusarium species and mycotoxins in silage maize. Toxins 2011, 3, 949-967. [CrossRef] [PubMed]

60. Ediage, E.N.; di Mavungu, J.D.; Monbaliu, S.; Van Peteghem, C.; De Saeger, S. A validated multianalyte LC-MS/MS method for quantification of 25 mycotoxins in cassava flour, peanut cake and maize samples. J. Agric. Food Chem. 2011, 59, 5173-5180. [CrossRef] [PubMed]

61. El Adlouni, C.; Tozlovanu, M.; Naman, F.; Faid, M.; Pfohl-Leszkowicz, A. Preliminary data on the presence of mycotoxins (ochratoxin A, citrinin and aflatoxin B1) in black table olives "Greek style" of Moroccan origin. Mol. Nutr. Food Res. 2006, 50, 507-512. [CrossRef] [PubMed]

62. Eskola, M.; Parikka, P.; Rizzo, A. Trichothecenes, ochratoxin A and zearalenone contamination and Fusarium infection in Finnish cereal samples in 1998. Food Addit. Contam. 2001, 18, 707-718. [CrossRef] [PubMed] 
63. Feng, Y.; Tao, B.; Pang, M.; Liu, Y.; Dong, J. Occurrence of major mycotoxins in maize from Hebei Province, China. Front. Agric. China 2011, 5, 497-503. [CrossRef]

64. Fernández Pinto, V.; Patriarca, A.; Locani, O.; Vaamonde, G. Natural co-occurrence of aflatoxin and cyclopiazonic acid in peanuts grown in Argentina. Food Addit. Contam. 2001, 18, 1017-1020. [CrossRef] [PubMed]

65. Ferreira, I.; Fernandes, J.O.; Cunha, S.C. Optimization and validation of a method based in a QuEChERS procedure and gas chromatography-mass spectrometry for the determination of multi-mycotoxins in popcorn. Food Control 2012, 27, 188-193. [CrossRef]

66. Fontaine, K.; Passeró, E.; Vallone, L.; Hymery, N.; Coton, M.; Jany, J.-L.; Mounier, J.; Coton, E. Occurrence of roquefortine $\mathrm{C}$, mycophenolic acid and aflatoxin $\mathrm{M} 1$ mycotoxins in blue-veined cheeses. Food Control 2015, 47, 634-640. [CrossRef]

67. Garrido, C.E.; Hernández Pezzani, C.; Pacin, A. Mycotoxins occurrence in Argentina's maize (Zea mays L.), from 1999 to 2010. Food Control 2012, 25, 660-665. [CrossRef]

68. Ghali, R.; Hmaissia-khlifa, K.; Ghorbel, H.; Maaroufi, K.; Hedili, A. Incidence of aflatoxins, ochratoxin A and zearalenone in tunisian foods. Food Control 2008, 19, 921-924. [CrossRef]

69. Gonzalez, H.H. L.; Martinez, E.J.; Pacin, A.M.; Resnik, S.L.; Sydenham, E.W. Natural co-occurrence of fumonisins, deoxynivalenol, zearalenone and aflatoxins in field trial corn in Argentina. Food Addit. Contam. 1999, 16, 565-569. [CrossRef] [PubMed]

70. González Pereyra, M.L.; Chiacchiera, S.M.; Rosa, C.A.; Sager, R.; Dalcero, A.M.; Cavaglieri, L. Comparative analysis of the mycobiota and mycotoxins contaminating corn trench silos and silo bags. J. Sci. Food Agric. 2011, 91, 1474-1481. [CrossRef] [PubMed]

71. Gutema, T.; Munimbazi, C.; Bullerman, L.B. Occurrence of fumonisins and moniliformin in corn and corn-based food products of U.S. origin. J. Food Prot. 2000, 63, 1732-1737. [PubMed]

72. Hajslova, J.; Lancova, K.; Sehnalova, M.; Krplova, A.; Zachariasova, M.; Moravcova, H.; Nedelnik, J.; Markova, J.; Ehrenbergerova, J. Occurrence of trichothecene mycotoxins in cereals harvested in the Czech Republic. Czech J. Food Sci. - UZPI Czech Repub. 2007, 25, 339-350.

73. Hasan, H.A.H. Patulin and aflatoxin in brown rot lesion of apple fruits and their regulation. World J. Microbiol. Biotechnol. 2000, 16, 607-612. [CrossRef]

74. Heperkan, D.; Somuncuoglu, S.; Karbancioglu-Güler, F.; Mecik, N. Natural contamination of cyclopiazonic acid in dried figs and co-occurrence of aflatoxin. Food Control 2012, 23, 82-86. [CrossRef]

75. Hernández Hierro, J.M.; Garcia-Villanova, R.J.; Rodríguez Torrero, P.; Toruño Fonseca, I.M. Aflatoxins and ochratoxin A in red paprika for retail sale in Spain: Occurrence and evaluation of a simultaneous analytical method. J. Agric. Food Chem. 2008, 56, 751-756. [CrossRef] [PubMed]

76. Ibáñez-Vea, M.; González-Peñas, E.; Lizarraga, E.; López de Cerain, A. Co-occurrence of aflatoxins, ochratoxin A and zearalenone in barley from a northern region of Spain. Food Chem. 2012, 132, 35-42. [CrossRef] [PubMed]

77. Ibáñez-Vea, M.; Martínez, R.; González-Peñas, E.; Lizarraga, E.; López de Cerain, A. Co-occurrence of aflatoxins, ochratoxin A and zearalenone in breakfast cereals from spanish market. Food Control 2011, 22, 1949-1955. [CrossRef]

78. Jaimez, J.; Fente, C.A.; Franco, C.M.; Cepeda, A.; Vázquez, B.I. A survey of the fungal contamination and presence of ochratoxin A and zearalenone on Spanish feed and raw materials. J. Sci. Food Agric. 2004, 84, 832-840. [CrossRef]

79. Jakšić, S.; Abramović, B.; Jajić, I.; Baloš, M.Ž.; Mihaljev, Ž.; Despotović, V.; Šojić, D. Co-occurrence of fumonisins and deoxynivalenol in wheat and maize harvested in Serbia. Bull. Environ. Contam. Toxicol. 2012, 89, 615-619. [CrossRef] [PubMed]

80. Jakšić, S.; Prunic, B.; Milanov, D.; Jajić, I.; Bjelica, L.; Abramovic, B. Fumonisins and co-occurring mycotoxins in north Serbian corn. Zb. Matice Srp. Za Prir. Nauke 2011, 49-59. [CrossRef]

81. Jestoi, M.; Rokka, M.; Yli-Mattila, T.; Parikka, P.; Rizzo, A.; Peltonen, K. Presence and concentrations of the Fusarium-related mycotoxins beauvericin, enniatins and moniliformin in finnish grain samples. Food Addit. Contam. 2004, 21, 794-802. [CrossRef] [PubMed]

82. Juan, C.; Mañes, J.; Raiola, A.; Ritieni, A. Evaluation of beauvericin and enniatins in Italian cereal products and multicereal food by liquid chromatography coupled to triple quadrupole mass spectrometry. Food Chem. 2013, 140, 755-762. [CrossRef] [PubMed] 
83. Juan, C.; Ritieni, A.; Mañes, J. Occurrence of Fusarium mycotoxins in Italian cereal and cereal products from organic farming. Food Chem. 2013, 141, 1747-1755. [CrossRef] [PubMed]

84. Jurjević, Z.; Solfrizzo, M.; Cvjetković, B.; de Girolamo, A.; Visconti, A. Occurrence of beauvericin in corn from Croatia. Food Technol Biotechnol 2002, 40, 91-94.

85. Jurjević, Ž.; Solfrizzo, M.; Cvjetković, B.; Avantaggiato, G.; Visconti, A. Occurrence of beauvericin in Croatia corn survey from 1996 to 1997. Phytopathology 2000, 90, 40.

86. Kabak, B. Aflatoxin M1 and ochratoxin A in baby formulae in Turkey: Occurrence and safety evaluation. Food Control 2012, 26, 182-187. [CrossRef]

87. Kabak, B. Determination of aflatoxins and ochratoxin A in retail cereal products from Turkey by high performance liquid chromatography with fluorescence detection. Food Control 2012, 28, 1-6. [CrossRef]

88. Kimanya, M.E.; De Meulenaer, B.; Tiisekwa, B.; Ndomondo-Sigonda, M.; Devlieghere, F.; Van Camp, J.; Kolsteren, P. Co-occurrence of fumonisins with aflatoxins in home-stored maize for human consumption in rural villages of Tanzania. Food Addit. Contam. Part Chem. Anal. Control Expo. Risk Assess. 2008, 25, 1353-1364. [CrossRef] [PubMed]

89. Kirinčič, S.; Škrjanc, B.; Kos, N.; Kozolc, B.; Pirnat, N.; Tavčar-Kalcher, G. Mycotoxins in cereals and cereal products in Slovenia-Official control of foods in the years 2008-2012. Food Control 2015, 50, 157-165. [CrossRef]

90. Klarić, M.S.; Cvetnić, Z.; Pepeljnjak, S.; Kosalec, I. Co-occurrence of aflatoxins, ochratoxin A, fumonisins, and zearalenone in cereals and feed, determined by competitive direct enzyme-linked immunosorbent assay and thin-layer chromatography. Arh. Hig. Rada Toksikol. 2009, 60, 427-434. [CrossRef] [PubMed]

91. Kokkonen, M.; Jestoi, M.; Rizzo, A. Determination of selected mycotoxins in mould cheeses with liquid chromatography coupled to tandem with mass spectrometry. Food Addit. Contam. 2005, 22, 449-456. [CrossRef] [PubMed]

92. Kpodo, K.; Thrane, U.; Hald, B. Fusaria and fumonisins in maize from Ghana and their co-occurrence with aflatoxins. Int. J. Food Microbiol. 2000, 61, 147-157. [CrossRef]

93. Labuda, R.; Parich, A.; Berthiller, F.; Tančinová, D. Incidence of trichothecenes and zearalenone in poultry feed mixtures from Slovakia. Int. J. Food Microbiol. 2005, 105, 19-25. [CrossRef] [PubMed]

94. Labuda, R.; Parich, A.; Vekiru, E.; Tancinová, D. Incidence of fumonisins, moniliformin and Fusarium species in poultry feed mixtures from Slovakia. Ann. Agric. Environ. Med. AAEM 2005, 12, 81-86. [PubMed]

95. Li, F.Q.; Yoshizawa, T.; Kawamura, O.; Luo, X.Y.; Li, Y.W. Aflatoxins and fumonisins in corn from the high-incidence area for human hepatocellular carcinoma in Guangxi, China. J. Agric. Food Chem. 2001, 49, 4122-4126. [CrossRef] [PubMed]

96. Logrieco, A.; Rizzo, A.; Ferracane, R.; Ritieni, A. Occurrence of beauvericin and enniatins in wheat affected by Fusarium avenaceum head blight. Appl. Environ. Microbiol. 2002, 68, 82-85. [CrossRef] [PubMed]

97. Mahnine, N.; Meca, G.; Elabidi, A.; Fekhaoui, M.; Saoiabi, A.; Font, G.; Mañes, J.; Zinedine, A. Further data on the levels of emerging Fusarium mycotoxins enniatins (A, A1, B, B1), beauvericin and fusaproliferin in breakfast and infant cereals from Morocco. Food Chem. 2011, 124, 481-485. [CrossRef]

98. Makun, H.A.; Dutton, M.F.; Njobeh, P.B.; Mwanza, M.; Kabiru, A.Y. Natural multi-occurrence of mycotoxins in rice from Niger State, Nigeria. Mycotoxin Res. 2011, 27, 97-104. [CrossRef] [PubMed]

99. Mankeviciene, A.; Butkute, B.; Dabkevicius, Z. Peculiarities of cereal grain co-contamination with Fusarium mycotoxins. Zemdirb.-Agric. 2011, 98, 415-420.

100. Martins, H.M.; Guerra, M.M.; Bernardo, F. Zearalenone, deoxynivalenol and fumonisins in mixed-feed for laying hens. Mycotoxin Res. 2006, 22, 206-210. [CrossRef] [PubMed]

101. Martins, M.L.; Gimeno, A.; Martins, H.M.; Bernardo, F. Co-occurrence of patulin and citrinin in Portuguese apples with rotten spots. Food Addit. Contam. 2002, 19, 568-574. [CrossRef] [PubMed]

102. Molinié, A.; Faucet, V.; Castegnaro, M.; Pfohl-Leszkowicz, A. Analysis of some breakfast cereals on the French market for their contents of ochratoxin A, citrinin and fumonisin B1: Development of a method for simultaneous extraction of ochratoxin A and citrinin. Food Chem. 2005, 92, 391-400. [CrossRef]

103. Monge, M.P.; Dalcero, A.M.; Magnoli, C.E.; Chiacchiera, S.M. Natural co-occurrence of fungi and mycotoxins in poultry feeds from Entre Ríos, Argentina. Food Addit. Contam. Part B Surveill. 2013, 6, 168-174. [CrossRef] [PubMed]

104. Montes, R.; Segarra, R.; Castillo, M.-Á. Trichothecenes in breakfast cereals from the Spanish retail market. J. Food Compos. Anal. 2012, 27, 38-44. [CrossRef] 
105. Moreno, E.C.; Garcia, G.T.; Ono, M.A.; Vizoni, É.; Kawamura, O.; Hirooka, E.Y.; Ono, E.Y.S. Co-occurrence of mycotoxins in corn samples from the Northern region of Paraná State, Brazil. Food Chem. 2009, 116, 220-226. [CrossRef]

106. Müller, H.-M.; Schwadorf, K. Natural occurrence of Fusarium toxins in barley grown in a southwestern area of Germany. Bull. Environ. Contam. Toxicol. 1993, 51, 532-537. [CrossRef] [PubMed]

107. Müller, H.-M.; Schwadorf, K. A survey of the natural occurrence of Fusarium toxins in wheat grown ina southwestern area of Germany. Mycopathologia 1993, 121, 115-121. [CrossRef]

108. Oliveira, C.A.; Rosmaninho, J.; Rosim, R. Aflatoxin M 1 and cyclopiazonic acid in fluid milk traded in São Paulo, Brazil. Food Addit. Contam. 2006, 23, 196-201. [CrossRef] [PubMed]

109. Ono, E.Y.S.; Ono, M.A.; Funo, F.Y.; Medina, A.E.; Oliveira IV, T.C.; Kawamura, O.; Ueno, Y.; Hirooka, E.Y. Evaluation of fumonisin-aflatoxin co-occurrence in Brazilian corn hybrids by ELISA. Food Addit. Contam. 2001, 18, 719-729. [CrossRef] [PubMed]

110. Ozbey, F.; Kabak, B. Natural co-occurrence of aflatoxins and ochratoxin A in spices. Food Control 2012, 28, 354-361. [CrossRef]

111. Perkowski, J.; Jeleń, H.; Kiecana, I.; Goliński, P. Natural contamination of spring barley with group A trichothecene mycotoxins in south-eastern Poland. Food Addit. Contam. 1997, 14, 321-325. [CrossRef] [PubMed]

112. Perkowski, J.; Basiński, T. Natural contamination of oat with group A trichothecene mycotoxins in Poland. Food Addit. Contam. 2002, 19, 478-482. [CrossRef] [PubMed]

113. Pettersson, H.; Brown, C.; Hauk, J.; Hoth, S.; Meyer, J.; Wessels, D. Survey of T-2 and HT-2 toxins by LC-MS/MS in oats and oat products from European oat mills in 2005-2009. Food Addit. Contam. Part B Surveill. Commun. 2011, 4, 110-115. [CrossRef] [PubMed]

114. Pfohl-Leszkowicz, A.; Tozlovanu, M.; Manderville, R.; Peraica, M.; Castegnaro, M.; Stefanovic, V. New molecular and field evidences for the implication of mycotoxins but not aristolochic acid in human nephropathy and urinary tract tumor. Mol. Nutr. Food Res. 2007, 51, 1131-1146. [CrossRef] [PubMed]

115. Raiola, A.; Meca, G.; Mañes, J.; Ritieni, A. Bioaccessibility of deoxynivalenol and its natural co-occurrence with ochratoxin A and aflatoxin B1 in Italian commercial pasta. Food Chem. Toxicol. 2012, 50, 280-287. [CrossRef] [PubMed]

116. Ritieni, A.; Moretti, A.; Logrieco, A.; Bottalico, A.; Randazzo, G.; Monti, S.M.; Ferracane, R.; Fogliano, V. Occurrence of Fusaproliferin, Fumonisin B1, and Beauvericin in Maize from Italy. J. Agric. Food Chem. 1997, 45, 4011-4016. [CrossRef]

117. Rocha, L.O.; Nakai, V.K.; Braghini, R.; Reis, T.A.; Kobashigawa, E.; Corrêa, B. Mycoflora and co-occurrence of fumonisins and aflatoxins in freshly harvested corn in different regions of Brazil. Int. J. Mol. Sci. 2009, 10, 5090-5103. [CrossRef] [PubMed]

118. Rodríguez-Carrasco, Y.; Moltó, J.C.; Berrada, H.; Mañes, J. A survey of trichothecenes, zearalenone and patulin in milled grain-based products using GC-MS/MS. Food Chem. 2014, 146, 212-219. [CrossRef] [PubMed]

119. Rodríguez-Carrasco, Y.; Ruiz, M.J.; Font, G.; Berrada, H. Exposure estimates to Fusarium mycotoxins through cereals intake. Chemosphere 2013, 93, 2297-2303. [CrossRef] [PubMed]

120. Rodríguez-Carrasco, Y.; Berrada, H.; Font, G.; Mañes, J. Multi-mycotoxin analysis in wheat semolina using an acetonitrile-based extraction procedure and gas chromatography-tandem mass spectrometry. J. Chromatogr. A 2012, 1270, 28-40. [CrossRef] [PubMed]

121. Sangare-Tigori, B.; Moukha, S.; Kouadio, H.J.; Betbeder, A.-M.; Dano, D.S.; Creppy, E.E. Co-occurrence of aflatoxin B1, fumonisin B1, ochratoxin A and zearalenone in cereals and peanuts from Côte d'Ivoire. Food Addit. Contam. 2006, 23, 1000-1007. [CrossRef] [PubMed]

122. Santos, L.; Marín, S.; Sanchis, V.; Ramos, A.J. Co-occurrence of aflatoxins, ochratoxin A and zearalenone in Capsicum powder samples available on the Spanish market. Food Chem. 2010, 122, 826-830. [CrossRef]

123. Schollenberger, M.; Müller, H.-M.; Rüfle, M.; Terry-Jara, H.; Suchy, S.; Plank, S.; Drochner, W. Natural occurrence of Fusarium toxins in soy food marketed in Germany. Int. J. Food Microbiol. 2007, 113, 142-146. [CrossRef] [PubMed]

124. Schollenberger, M.; Müller, H.-M.; Rüfle, M.; Suchy, S.; Planck, S.; Drochner, W. Survey of Fusarium toxins in foodstuffs of plant origin marketed in Germany. Int. J. Food Microbiol. 2005, 97, 317-326. [CrossRef] [PubMed] 
125. Schollenberger, M.; Suchy, S.; Jara, H.T.; Drochner, W.; MÜller, H.-M. A survey of Fusarium toxins in cereal-based foods marketed in an area of southwest Germany. Mycopathologia 1999, 147, 49-57. [CrossRef] [PubMed]

126. Sedmikova, M.; Reisnerova, H.; Dufkova, Z.; Jilek, F.; Barta, I. Potential hazard of simultaneous occurrence of aflatoxin B1 and ochratoxin A. Vet. Med.-UZPI Czech Repub. 2001, 46, 169-174.

127. Senyuva, H.Z.; Gilbert, J.; Ozcan, S.; Ulken, U. Survey for co-occurrence of ochratoxin A and aflatoxin B1 in dried figs in Turkey by using a single laboratory-validated alkaline extraction method for ochratoxin A. J. Food Prot. 2005, 68, 1512-1515. [PubMed]

128. Serrano, A.B.; Font, G.; Mañes, J.; Ferrer, E. Emerging Fusarium mycotoxins in organic and conventional pasta collected in Spain. Food Chem. Toxicol. 2013, 51, 259-266. [CrossRef] [PubMed]

129. Serrano, A.B.; Font, G.; Ruiz, M.J.; Ferrer, E. Co-occurrence and risk assessment of mycotoxins in food and diet from Mediterranean area. Food Chem. 2012, 135, 423-429. [CrossRef] [PubMed]

130. Sifou, A.; Meca, G.; Serrano, A.B.; Mahnine, N.; El Abidi, A.; Mañes, J.; El Azzouzi, M.; Zinedine, A. First report on the presence of emerging Fusarium mycotoxins enniatins (A, A1, B, B1), beauvericin and fusaproliferin in rice on the Moroccan retail markets. Food Control 2011, 22, 1826-1830. [CrossRef]

131. Sultana, N.; Rashid, A.; Tahira, I.; Hanif, H.U.; Hanif, N.Q. Distribution of various mycotoxins in compound feed, total mix ration and silage. Pak. Vet. J. Pak. 2013.

132. Sun, G.; Wang, S.; Hu, X.; Su, J.; Zhang, Y.; Xie, Y.; Zhang, H.; Tang, L.; Wang, J.-S. Co-contamination of aflatoxin B1 and fumonisin B1 in food and human dietary exposure in three areas of China. Food Addit. Contam. Part Chem. Anal. Control Expo. Risk Assess. 2011, 28, 461-470. [CrossRef] [PubMed]

133. Tanaka, T.; Yamamoto, S.; Hasegawa, A.; Aoki, N.; Besling, J.R.; Sugiura, Y.; Ueno, Y. A survey of the natural occurrence of Fusarium mycotoxins, deoxynivalenol, nivalenol and zearalenone, in cereals harvested in the Netherlands. Mycopathologia 1990, 110, 19-22. [CrossRef] [PubMed]

134. Tanaka, T.; Hasegawa, A.; Yamamoto, S.; Sugiura, Y.; Ueno, Y. A case report on a minor contamination of nivalenol in cereals harvested in Canada. Mycopathologia 1988, 101, 157-160. [CrossRef] [PubMed]

135. Ueno, Y.; Iijima, K.; Wang, S.-D.; Sugiura, Y.; Sekijima, M.; Tanaka, T.; Chen, C.; Yu, S.-Z. Fumonisins as a possible contributory risk factor for primary liver cancer: A 3-year study of corn harvested in Haimen, China, by HPLC and ELISA. Food Chem. Toxicol. 1997, 35, 1143-1150. [CrossRef]

136. Varga, E.; Glauner, T.; Berthiller, F.; Krska, R.; Schuhmacher, R.; Sulyok, M. Development and validation of a (semi-)quantitative UHPLC-MS/MS method for the determination of 191 mycotoxins and other fungal metabolites in almonds, hazelnuts, peanuts and pistachios. Anal. Bioanal. Chem. 2013, 405, 5087-5104. [CrossRef] [PubMed]

137. Vargas, E.A.; Preis, R.A.; Castro, L.; Silva, C.M. Co-occurrence of aflatoxins B1, B2, G1, G2, zearalenone and fumonisin B1 in Brazilian corn. Food Addit. Contam. 2001, 18, 981-986. [CrossRef] [PubMed]

138. Villa, P.; Markaki, P. Aflatoxin B1 and ochratoxin A in breakfast cereals from athens market: Occurrence and risk assessment. Food Control 2009, 20, 455-461. [CrossRef]

139. Vrabcheva, T.; Usleber, E.; Dietrich, R.; Märtlbauer, E. Co-occurrence of ochratoxin A and citrinin in cereals from Bulgarian villages with a history of Balkan endemic nephropathy. J. Agric. Food Chem. 2000, 48, 2483-2488. [CrossRef] [PubMed]

140. Wang, D.-S.; Liang, Y.-X.; Chau, N.T.; Dien, L.D.; Tanaka, T.; Ueno, Y. Natural co-occurrence of Fusarium toxins and aflatoxin B1 in com for feed in North Vietnam. Nat. Toxins 1995, 3, 445-449. [CrossRef] [PubMed]

141. Yamashita, A.; Yoshizawa, T.; Aiura, Y.; Sanchez, P.C.; Dizon, E.I.; Arim, R.H.; Sardjono. Fusarium mycotoxins (fumonisins, nivalenol, and zearalenone) and aflatoxins in corn from Southeast Asia. Biosci. Biotechnol. Biochem. 1995, 59, 1804-1807. [CrossRef] [PubMed]

142. Yoshizawa, T.; Yamashita, A.; Chokethaworn, N. Occurrence of fumonisins and aflatoxins in corn from Thailand. Food Addit. Contam. 1996, 13, 163-168. [CrossRef] [PubMed]

143. Zinedine, A.; Brera, C.; Elakhdari, S.; Catano, C.; Debegnach, F.; Angelini, S.; De Santis, B.; Faid, M.; Benlemlih, M.; Minardi, V.; Miraglia, M. Natural occurrence of mycotoxins in cereals and spices commercialized in Morocco. Food Control 2006, 17, 868-874. [CrossRef]

144. BIOMIN. Science \& Solutions; BIOMIN Holding GmbH: Herzogenburg, Austria, 2015.

145. Merhej, J.; Richard-Forget, F.; Barreau, C. Regulation of trichothecene biosynthesis in Fusarium: Recent advances and new insights. Appl. Microbiol. Biotechnol. 2011, 91, 519-528. [CrossRef] [PubMed] 
146. Gareis, M.; Zimmerman, C.; Schothorst, R.; Paulsch, W.; Vidnes, A.; Bergsten, C.; Paulsen, B.; Brera, C.; Maraglia, M.; Grossi, S.; et al. Collection of occurrence data of Fusarium toxins in food and assessment of dietary intake by the population of EU member states; Directorate-General Health and Consumer Protection: Kulmbach, Germany; Berlin, Germany; Bilthoven, The Netherlands; Oslo, Norway; Rome, Italy, 2003; p. 606.

147. Miraglia, M.; Brera, C. Assessment of dietary intake of ochratoxin A by the population of EU Member States; Directorate-General Health and Consumer Protection: Rome, Italy, 2002; p. 153.

148. Bennett, J.W.; Klich, M. Mycotoxins. Clin. Microbiol. Rev. 2003, 16, 497-516. [CrossRef] [PubMed]

149. Pereira, V.L.; Fernandes, J.O.; Cunha, S.C. Mycotoxins in cereals and related foodstuffs: A review on occurrence and recent methods of analysis. Trends Food Sci. Technol. 2014, 36, 96-136. [CrossRef]

150. Paterson, R.R.M.; Lima, N. How will climate change affect mycotoxins in food? Food Res. Int. 2010, 43, 1902-1914. [CrossRef]

151. Paterson, R.R.M.; Lima, N. Further mycotoxin effects from climate change. Food Res. Int. 2011, 44, $2555-2566$. [CrossRef]

152. Klarić, M.Š. Adverse effects of combined mycotoxins/Štetni učinci kombiniranih mikotoksina. Arch. Ind. Hyg. Toxicol. 2012, 63, 519-530.

153. Richard, J.L. Some major mycotoxins and their mycotoxicoses-An overview. Int. J. Food Microbiol. 2007, 119, 3-10. [CrossRef] [PubMed]

154. Alassane-Kpembi, I.; Puel, O.; Oswald, I.P. Toxicological interactions between the mycotoxins deoxynivalenol, nivalenol and their acetylated derivatives in intestinal epithelial cells. Arch. Toxicol. 2015, 89, 1337-1346. [CrossRef] [PubMed]

155. Alassane-Kpembi, I.; Kolf-Clauw, M.; Gauthier, T.; Abrami, R.; Abiola, F.A.; Oswald, I.P.; Puel, O. New insights into mycotoxin mixtures: The toxicity of low doses of Type B trichothecenes on intestinal epithelial cells is synergistic. Toxicol. Appl. Pharmacol. 2013, 272, 191-198. [CrossRef] [PubMed]

156. Bensassi, F.; Gallerne, C.; Sharaf el dein, O.; Hajlaoui, M.R.; Lemaire, C.; Bacha, H. In vitro investigation of toxicological interactions between the fusariotoxins deoxynivalenol and zearalenone. Toxicon 2014, 84, 1-6. [CrossRef] [PubMed]

157. Bernhoft, A.; Keblys, M.; Morrison, E.; Larsen, H.J.S.; Flåøyen, A. Combined effects of selected Penicillium mycotoxins on in vitro proliferation of porcine lymphocytes. Mycopathologia 2004, 158, 441-450. [CrossRef] [PubMed]

158. Bouaziz, C.; Bouslimi, A.; Kadri, R.; Zaied, C.; Bacha, H.; Abid-Essefi, S. The in vitro effects of zearalenone and T-2 toxins on Vero cells. Exp. Toxicol. Pathol. 2013, 65, 497-501. [CrossRef] [PubMed]

159. Bouslimi, A.; Bouaziz, C.; Ayed-Boussema, I.; Hassen, W.; Bacha, H. Individual and combined effects of ochratoxin A and citrinin on viability and DNA fragmentation in cultured Vero cells and on chromosome aberrations in mice bone marrow cells. Toxicology 2008, 251, 1-7. [CrossRef] [PubMed]

160. Bouslimi, A.; Ouannes, Z.; Golli, E.E.; Bouaziz, C.; Hassen, W.; Bacha, H. Cytotoxicity and oxidative damage in kidney cells exposed to the mycotoxins ochratoxin A and citrinin: Individual and combined effects. Toxicol. Mech. Methods 2008, 18, 341-349. [CrossRef] [PubMed]

161. Braunberg, R.C.; Barton, C.N.; Gantt, O.O.; Friedman, L. Interaction of citrinin and ochratoxin A. Nat. Toxins 1994, 2, 124-131. [CrossRef] [PubMed]

162. Corcuera, L.A.; Arbillaga, L.; Vettorazzi, A.; Azqueta, A.; López de Cerain, A. Ochratoxin A reduces aflatoxin B1 induced DNA damage detected by the comet assay in Hep G2 cells. Food Chem. Toxicol. 2011, 49, 2883-2889. [CrossRef] [PubMed]

163. Creppy, E.E.; Chiarappa, P.; Baudrimont, I.; Borracci, P.; Moukha, S.; Carratù, M.R. Synergistic effects of fumonisin B1 and ochratoxin A: Are in vitro cytotoxicity data predictive of in vivo acute toxicity? Toxicology 2004, 201, 115-123. [CrossRef] [PubMed]

164. Creppy, E.-E.; Lorkowski, G.; Beck, G.; Röschenthaler, R.; Dirheimer, G. Combined action of citrinin and ochratoxin A on hepatoma tissue culture cells. Toxicol. Lett. 1980, 5, 375-380. [CrossRef]

165. Dombrink-Kurtzman, M.A. Fumonisin and beauvericin induce apoptosis in turkey peripheral blood lymphocytes. Mycopathologia 2003, 156, 357-364. [CrossRef] [PubMed]

166. Ficheux, A.S.; Sibiril, Y.; Parent-Massin, D. Co-exposure of Fusarium mycotoxins: in vitro myelotoxicity assessment on human hematopoietic progenitors. Toxicon 2012, 60, 1171-1179. [CrossRef] [PubMed]

167. Föllmann, W.; Behm, C.; Degen, G.H. Toxicity of the mycotoxin citrinin and its metabolite dihydrocitrinone and of mixtures of citrinin and ochratoxin A in vitro. Arch. Toxicol. 2014, 88, 1097-1107. [CrossRef] [PubMed] 
168. Föllmann, W.; Lebrun, S.; Kullik, B.; Koch, M.; Römer, H.C.; Golka, K. Cytotoxicity of ochratoxin A and citrinin in different cell types in vitro. Mycotoxin Res. 2000, 16, 123-126. [CrossRef] [PubMed]

169. Fontaine, K.; Mounier, J.; Coton, E.; Hymery, N. Individual and combined effects of roquefortine C and mycophenolic acid on human monocytic and intestinal cells. World Mycotoxin J. 2015, 1-11. [CrossRef]

170. Gayathri, L.; Dhivya, R.; Dhanasekaran, D.; Periasamy, V.S.; Alshatwi, A.A.; Akbarsha, M.A. Hepatotoxic effect of ochratoxin A and citrinin, alone and in combination, and protective effect of vitamin E: In vitro study in HepG2 cell. Food Chem. Toxicol. 2015, 83, 151-163. [CrossRef] [PubMed]

171. Golli-Bennour, E.E.; Kouidhi, B.; Bouslimi, A.; Abid-Essefi, S.; Hassen, W.; Bacha, H. Cytotoxicity and genotoxicity induced by aflatoxin B1, ochratoxin A, and their combination in cultured Vero cells. J. Biochem. Mol. Toxicol. 2010, 24, 42-50. [CrossRef] [PubMed]

172. He, C.-H.; Fan, Y.-H.; Wang, Y.; Huang, C.-Y.; Wang, X.-C.; Zhang, H.-B. The individual and combined effects of deoxynivalenol and aflatoxin B1 on primary hepatocytes of Cyprinus carpio. Int. J. Mol. Sci. 2010, 11, 3760-3768. [CrossRef] [PubMed]

173. Heussner, A.H.; Dietrich, D.R.; O’Brien, E. In vitro investigation of individual and combined cytotoxic effects of ochratoxin A and other selected mycotoxins on renal cells. Toxicol. In Vitro 2006, 20, 332-341. [CrossRef] [PubMed]

174. Heussner, A.H.; O’Brien, E.; Haehnlein, J.; Biester, M.A.; Dietrich, D.R. Comparison of interactive cytotoxic effects of selected mycotoxins on renal cells. Toxicol. Sci. 2004, 78, 89.

175. Klarić, M.Š.; Medić, N.; Hulina, A.; Žanić Grubišić, T.; Rumora, L. Disturbed Hsp70 and Hsp27 expression and thiol redox status in porcine kidney PK15 cells provoked by individual and combined ochratoxin A and citrinin treatments. Food Chem. Toxicol. 2014, 71, 97-105. [CrossRef] [PubMed]

176. Klarić, M.Š.; Želježić, D.; Rumora, L.; Peraica, M.; Pepeljnjak, S.; Domijan, A.-M. A potential role of calcium in apoptosis and aberrant chromatin forms in porcine kidney PK15 cells induced by individual and combined ochratoxin A and citrinin. Arch. Toxicol. 2012, 86, 97-107. [CrossRef] [PubMed]

177. Klarić, M.Š.; Daraboš, D.; Rozgaj, R.; Kašuba, V.; Pepeljnjak, S. Beauvericin and ochratoxin A genotoxicity evaluated using the alkaline comet assay: single and combined genotoxic action. Arch. Toxicol. 2010, 84, 641-650. [CrossRef] [PubMed]

178. Klarić, M.Š.; Pepeljnjak, S.; Rozgaj, R. Genotoxicity of fumonisin B1, beauvericin and ochratoxin A in porcine kidney PK15 cells: Effects of individual and combined treatment. Croat. Chem. Acta 2008, 81, 139-146.

179. Klarić, M.Š.; Rumora, L.; Ljubanović, D.; Pepeljnjak, S. Cytotoxicity and apoptosis induced by fumonisin B1, beauvericin and ochratoxin A in porcine kidney PK15 cells: effects of individual and combined treatment. Arch. Toxicol. 2008, 82, 247-255. [CrossRef] [PubMed]

180. Klarić, M.Š.; Pepeljnjak, S.; Domijan, A.-M.; Petrik, J. Lipid peroxidation and glutathione levels in porcine kidney PK15 cells after individual and combined treatment with fumonisin B1, beauvericin and ochratoxin A. Basic Clin. Pharmacol. Toxicol. 2006, 100, 157-164. [CrossRef] [PubMed]

181. Knecht, A.; Schwerdt, G.; Gekle, M.; Humpf, H.-U. Combinatory effects of citrinin and ochratoxin A in immortalized human proximal tubule cells. Mycotoxin Res. 2005, 21, 176-181. [CrossRef] [PubMed]

182. Koshinsky, H.A.; Hannan, P.J.; Khachatourians, G.G. HT-2 toxin, roridin A, T-2 toxin, and verrucarin A mycotoxins inhibit carbon dioxide production by Kluyveromyces marxianus. Can. J. Microbiol. 1991, 37, 933-938. [CrossRef]

183. Koshinsky, H.A.; Khachatourians, G.G. Trichothecene synergism, additivity, and antagonism: The significance of the maximally quiescent ratio. Nat. Toxins 1992, 1, 38-47. [CrossRef] [PubMed]

184. Koshinsky, H.A.; Khachatourians, G.G. Bioassay for deoxynivalenol based on the interaction of T-2 toxin with trichothecene mycotoxins. Bull. Environ. Contam. Toxicol. 1992, 49, 246-251. [CrossRef] [PubMed]

185. Kouadio, J.H.; Brou, K.; Gnakri, D. Low level of ochratoxin A enhances aflatoxin B1 induced cytotoxicity and lipid peroxydation in both human intestinal (Caco-2) and hepatoma (HepG2) cells lines. Int. J. Nutr. Food Sci. 2013, 2, 294-300.

186. Kouadio, J.H.; Moukha, S.; Brou, K.; Gnakri, D. Modulation of fumonisin B1 toxic action-induced by zeralenone in human intestinal cells Caco-2. Int. J. Sci. Technol. Res. 2013, 2, 315-320.

187. Kouadio, J.H.; Dano, S.D.; Moukha, S.; Mobio, T.A.; Creppy, E.E. Effects of combinations of Fusarium mycotoxins on the inhibition of macromolecular synthesis, malondialdehyde levels, DNA methylation and fragmentation, and viability in Caco-2 cells. Toxicon 2007, 49, 306-317. [CrossRef] [PubMed] 
188. Lei, M.; Zhang, N.; Qi, D. In vitro investigation of individual and combined cytotoxic effects of aflatoxin B1 and other selected mycotoxins on the cell line porcine kidney 15. Exp. Toxicol. Pathol. 2013, 65, 1149-1157. [CrossRef] [PubMed]

189. Lu, H.; Fernández-Franzón, M.; Font, G.; Ruiz, M.J. Toxicity evaluation of individual and mixed enniatins using an in vitro method with CHO-K1 cells. Toxicol. In Vitro 2013, 27, 672-680. [CrossRef] [PubMed]

190. Luongo, D.; De Luna, R.; Russo, R.; Severino, L. Effects of four Fusarium toxins (fumonisin B1, $\alpha$-zearalenol, nivalenol and deoxynivalenol) on porcine whole-blood cellular proliferation. Toxicon 2008, 52, 156-162. [CrossRef] [PubMed]

191. Luongo, D.; Severino, L.; Bergamo, P.; De Luna, R.; Lucisano, A.; Rossi, M. Interactive effects of fumonisin $\mathrm{B} 1$ and $\alpha$-zearalenol on proliferation and cytokine expression in Jurkat T cells. Toxicol. In Vitro 2006, 20, 1403-1410. [CrossRef] [PubMed]

192. Madhyastha, M.S.; Marquardt, R.R.; Abramson, D. Structure-activity relationships and interactions among trichothecene mycotoxins as assessed by yeast bioassay. Toxicon 1994, 32, 1147-1152. [CrossRef]

193. Manderville, R.; Pfohl-Leszkowicz, A. Bioactivation and DNA adduction as a rationale for ochratoxin A carcinogenesis. World Mycotoxin J. 2008, 1, 357-367. [CrossRef]

194. Marzocco, S.; Russo, R.; Bianco, G.; Autore, G.; Severino, L. Pro-apoptotic effects of nivalenol and deoxynivalenol trichothecenes in J774A.1 murine macrophages. Toxicol. Lett. 2009, 189, 21-26. [CrossRef] [PubMed]

195. McKean, C.; Tang, L.; Tang, M.; Billam, M.; Wang, Z.; Theodorakis, C.W.; Kendall, R.J.; Wang, J.-S. Comparative acute and combinative toxicity of aflatoxin B1 and fumonisin B1 in animals and human cells. Food Chem. Toxicol. 2006, 44, 868-876. [CrossRef] [PubMed]

196. Prosperini, A.; Font, G.; Ruiz, M.J. Interaction effects of Fusarium enniatins (A, A1, B and B1) combinations on in vitro cytotoxicity of Caco-2 cells. Toxicol. In Vitro 2014, 28, 88-94. [CrossRef] [PubMed]

197. Ruiz, M.-J.; Franzova, P.; Juan-García, A.; Font, G. Toxicological interactions between the mycotoxins beauvericin, deoxynivalenol and T-2 toxin in CHO-K1 cells in vitro. Toxicon 2011, 58, 315-326. [CrossRef] [PubMed]

198. Ruiz, M.-J.; Macáková, P.; Juan-García, A.; Font, G. Cytotoxic effects of mycotoxin combinations in mammalian kidney cells. Food Chem. Toxicol. 2011, 49, 2718-2724. [CrossRef] [PubMed]

199. Rumora, L.; Domijan, A.-M.; Žanić Grubišić, T.; Klarić, M.Š. Differential activation of MAPKs by individual and combined ochratoxin A and citrinin treatments in porcine kidney PK15 cells. Toxicon 2014, 90, 174-183. [CrossRef] [PubMed]

200. Severino, L.; Luongo, D.; Bergamo, P.; Lucisano, A.; Rossi, M. Mycotoxins nivalenol and deoxynivalenol differentially modulate cytokine mRNA expression in Jurkat T cells. Cytokine 2006, 36, 75-82. [CrossRef] [PubMed]

201. Stoev, S.; Denev, S.; Dutton, M.; Nkosi, B. Cytotoxic effect of some mycotoxins and their combinations on human peripheral blood mononuclear cells as measured by the MTT assay. Open Toxinology J. 2009, 2, 1-8. [CrossRef]

202. Tajima, O.; Schoen, E.D.; Feron, V.J.; Groten, J.P. Statistically designed experiments in a tiered approach to screen mixtures of Fusarium mycotoxins for possible interactions. Food Chem. Toxicol. 2002, 40, 685-695. [CrossRef]

203. Tammer, B.; Lehmann, I.; Nieber, K.; Altenburger, R. Combined effects of mycotoxin mixtures on human $\mathrm{T}$ cell function. Toxicol. Lett. 2007, 170, 124-133. [CrossRef] [PubMed]

204. Tatay, E.; Meca, G.; Font, G.; Ruiz, M.-J. Interactive effects of zearalenone and its metabolites on cytotoxicity and metabolization in ovarian CHO-K1 cells. Toxicol. In Vitro 2014, 28, 95-103. [CrossRef] [PubMed]

205. Theumer, M.G.; Cánepa, M.C.; López, A.G.; Mary, V.S.; Dambolena, J.S.; Rubinstein, H.R. Subchronic mycotoxicoses in Wistar rats: Assessment of the in vivo and in vitro genotoxicity induced by fumonisins and aflatoxin B1, and oxidative stress biomarkers status. Toxicology 2010, 268, 104-110. [CrossRef] [PubMed]

206. Thompson, W.L.; Wannemacher, R.W., Jr. Structure-function relationships of 12,13-epoxytrichothecene mycotoxins in cell culture: Comparison to whole animal lethality. Toxicon 1986, 24, 985-994. [CrossRef]

207. Thuvander, A.; Wikman, C.; Gadhasson, I. In vitro exposure of human lymphocytes to trichothecenes: Individual variation in sensitivity and effects of combined exposure on lymphocyte function. Food Chem. Toxicol. 1999, 37, 639-648. [CrossRef] 
208. Wang, H.W.; Wang, J.Q.; Zheng, B.Q.; Li, S.L.; Zhang, Y.D.; Li, F.D.; Zheng, N. Cytotoxicity induced by ochratoxin A, zearalenone, and $\alpha$-zearalenol: Effects of individual and combined treatment. Food Chem. Toxicol. 2014, 71, 217-224. [CrossRef] [PubMed]

209. Wan, L.Y.M.; Turner, P.C.; El-Nezami, H. Individual and combined cytotoxic effects of Fusarium toxins (deoxynivalenol, nivalenol, zearalenone and fumonisins B1) on swine jejunal epithelial cells. Food Chem. Toxicol. 2013, 57, 276-283. [CrossRef] [PubMed]

210. Anninou, N.; Chatzaki, E.; Papachristou, F.; Pitiakoudis, M.; Simopoulos, C. Mycotoxins' activity at toxic and sub-toxic concentrations: differential cytotoxic and genotoxic effects of single and combined administration of sterigmatocystin, ochratoxin A and citrinin on the hepatocellular cancer cell line Hep3B. Int. J. Environ. Res. Public. Health 2014, 11, 1855-1872. [CrossRef] [PubMed]

211. Klarić, M.Š.; Rašić, D.; Peraica, M. Deleterious effects of mycotoxin combinations involving ochratoxin A. Toxins 2013, 5, 1965-1987. [CrossRef] [PubMed]

212. Weber, F.; Freudinger, R.; Schwerdt, G.; Gekle, M. A rapid screening method to test apoptotic synergisms of ochratoxin A with other nephrotoxic substances. Toxicol. In Vitro 2005, 19, 135-143. [CrossRef] [PubMed]

213. Chou, T.-C.; Talalay, P. Quantitative analysis of dose-effect relationships: the combined effects of multiple drugs or enzyme inhibitors. Adv. Enzyme Regul. 1984, 22, 27-55. [CrossRef]

214. Chou, T.-C. Theoretical basis, experimental design, and computerized simulation of synergism and antagonism in drug combination studies. Pharmacol. Rev. 2006, 58, 621-681. [CrossRef] [PubMed]

(C) 2016 by the authors; licensee MDPI, Basel, Switzerland. This article is an open access article distributed under the terms and conditions of the Creative Commons by Attribution (CC-BY) license (http://creativecommons.org/licenses/by/4.0/). 